\title{
Development and Diseases of the Collecting Duct System
}

\author{
Lihe Chen ${ }^{1}$, Paul J. Higgins ${ }^{2}$, Wenzheng Zhang ${ }^{2,}$ \\ ${ }^{1}$ Epithelial Systems Biology Laboratory, Systems Biology Center, NHLBI, Bethesda, MD \\ 20892-1603, USA \\ 2Department of Regenerative \& Cancer Cell Biology, Albany Medical College, MC-165, 47 New \\ Scotland Avenue, Albany, New York 12208.
}

\begin{abstract}
The collecting duct of the mammalian kidney is important for the regulation of extracellular volume, osmolarity, and $\mathrm{pH}$. There are two major structurally and functionally distinct cell types: principal cells and intercalated cells. The former regulates $\mathrm{Na}^{+}$and water homeostasis while the latter participates in acid-base homeostasis. In vivo lineage tracing using Cre recombinase or its derivatives such as CreGFP and CreER ${ }^{\mathrm{T} 2}$ is a powerful new technique to identify stem/progenitor cells in their native environment and to decipher the origins of the tissue that they give rise to. Recent studies using this technique in mice have revealed multiple renal progenitor cell populations that differentiate into various nephron segments and collecting duct. In particular, emerging evidence suggests that like principal cells, most of intercalated cells originate from the progenitor cells expressing water channel Aquaporin 2. Mutations or malfunctions of the channels, pumps, and transporters expressed in the collecting duct system cause various human diseases. For example, gain-of-function mutations in ENaC cause Liddle's syndrome while loss-of-function mutations in ENaC lead to Pseudohypoaldosteronism type 1. Mutations in either AE1 or V-ATPase B1 result in distal renal tubular acidosis. Patients with disrupted AQP2 or AVPR2 develop nephrogenic diabetes insipidus. A better understanding of the function and development of the collecting duct system may facilitate the discovery of new therapeutic strategies for treating kidney disease.
\end{abstract}

\section{Kidney structure and function}

The adult kidney is a complex filtration system structurally comprised of discrete cell types including glomerulus parietal cells, glomerulus podocytes, proximal tubule brush border cells, loop of Henle thin segment cells, thick ascending limb cells, collecting duct principal cells (PC), collecting duct intercalated cells (IC), and stromal cells. They reside in the cortex, medulla, and papilla regions. In humans, a normal kidney contains 800,000 to 1.5 million nephrons (Guyton and Hall 2006), which are the basic filtering and excretory renal units. The differentiated segments of each nephron, from proximal to distal, consist of the glomerulus, proximal tubule, loop of Henle, and distal convoluted tubule. A series of tubules and ducts connects the nephrons to the ureter and is referred as the collecting duct system.

\footnotetext{
*Correspondence: zhangw1@ mail.amc.edu.
} 
The major functions of the kidney are 1) maintenance of electrolyte, water, and acid-base balance; 2) excretion of nitrogenous waste metabolites; 3 ) hormonal secretion; and 4) regulation of blood pressure. They filter about 180 liters of blood per day, with only about 1.5 liters finally leaving the body as urine. Urine is formed by nephrons through three precisely regulated processes: filtration, reabsorption, and secretion.

Blood flows into the glomerulus through the afferent arteriole. The filtration barrier prevents the passage of albumin and blood cells. These large substances exit the glomerulus via the efferent arteriole. In contrast, small molecules including ions, water, sugar, and nitrogenous waste are passed through the barrier into Bowman's capsule to produce the glomerular filtrate.

Reabsorption, the next step in urine formation, is the process during which ions and water are reabsorbed back into the bloodstream. This is achieved when the glomerular filtrate passes through the proximal tubule, the loop of Henle, and the distal convoluted tubule, and the collecting duct system. The resulting product after reabsorption in the nephron is known as the tubular fluid.

Secretion takes place in the epithelial cells that form the renal tubules and collecting ducts and involves the removal of excessive quantities of certain dissolved substances in the blood to the tubular fluid. Secretion also keeps the blood at a normal $\mathrm{pH}$, which typically ranges from $\mathrm{pH} 7.35$ to $\mathrm{pH} 7.45$.

\section{Different origins of the collecting duct and nephron during development}

\section{1. Ureteric bud and metanephric mesenchyme}

In mammals, the pronephros and mesonephros exist transiently (Little and McMahon 2012). Mouse nephrogenesis, which starts at E11, is characterized by an outgrowth of the ureteric bud from the Wolffian duct and an extensive invasion of the ureteric bud into the surrounding metanephric mesenchyme (Little and McMahon 2012). At this stage, the ureteric bud is evident as a T-shape structure and thereafter undergoes a series of branching morphogenesis. The ureteric bud is able to undergo multiple rounds of branching and creates the whole collecting duct system. Signals secreted from the ureteric bud tip induce the surrounding mesenchymal cells to produce cap mesenchyme, and initiate the mesenchymeto-epithelial transition of the cap mesenchyme to generate the early nephron structures. The induced cap mesenchyme cells around the ureteric bud tip form the renal vesicles with a small lumen. The comma shaped body then develops with the appearance of a cleft in the renal vesicles. The s-shaped body becomes evident when a second cleft appears in the comma-shaped body. The distal end of the s-shaped structure attaches to the ureteric bud and forms the continuous tubule through a yet undefined mechanism, while the proximal part of the s-shaped body interacts with endothelial cells to begin glomerulogenesis.

The metanephric mesenchyme is a pool for renal stem and progenitor cells. In addition to giving rise to the entire nephron complement, the stem or progenitor cells within the metanephric mesenchyme also give rise to either vascular progenitors to create the blood 
vessels (Mugford et al. 2008), or stromal progenitors to generate the stromal tissues (Little and McMahon 2012; Humphreys et al. 2010). With the continuation of ureteric bud branching, new ureteric bud tips form and repeat the same process. Connection of the nephrons with the ureteric bud allows the urine to be voided continuously via the ureters.

\subsection{In vivo genetic lineage tracing, a powerful tool to identify the stem/progenitor cells}

Identification, and clarifying the biology, of the stem and progenitor cell cohorts within the organ hold promise to translate stem cell research to clinical applications. Lineage tracing represents the most powerful tool to identify the stem/progenitor cells in their native environment and decipher the origins of the tissue that they give rise to.

The key components of the genetic lineage tracing technique include Cre recombinase and Cre-dependent reporters. Cre recombinase is an enzyme that catalyzes the recombination of DNA between two loxP target cleavage sites. A loxP site consists of 34 base pairs (bp) with two 13-bp palindromic sequences separated by an 8-bp spacer region. A floxed allele is one that is placed between two loxP sites. Cre recognizes the loxP targets and mediates the deletion or reversion of the floxed DNA sequence, when the two loxP sites are in the same or opposite direction (Nagy 2000; Humphreys and DiRocco 2014), respectively.

In genetic lineage tracing experiments, one mouse line carries a transgene or a knock-in construct that drives Cre expression under control of a tissue- or cell-type specific promoter. This line is often referred as a deletor or Cre driver. The Cre driver is crossed to a second mouse line harboring a Cre-dependent reporter, such as red fluorescent protein (RFP) or LacZ. In case of RFP, RFP is designed to be under the control of a ubiquitous promoter, usually consisting of a CMV-IE enhancer/chicken $\beta$-Actin/rabbit $\beta$-Globin hybrid promoter (CAG) in which the RFP coding sequence and CAG promoter is constructed as a loxPflanked "STOP" cassette, which prevents transcription of the reporter (Madisen et al. 2010). In double transgenic mice harboring both a Cre driver and a RFP reporter, Cre recombinasemediated recombination deletes the "STOP" cassette resulting in expression of RFP in the Cre-expressing tissue(s) or cells. Because CAG is a ubiquitously active promoter that is silenced by the "STOP" cassette, RFP expression is achieved only in the tissue(s)/cells that express Cre recombinase to remove the "STOP" cassette. Once a cell activates RFP, its offspring also have a permanently deleted "STOP" cassette, which provides for persistent expression of RFP, leading to a population of RFP-traced cells. This technique is extremely useful in stem cell research, especially in organs with complex cellular hierarchies like the kidney (Humphreys and DiRocco 2014).

In addition, several Cre fusion proteins have been described, including CreGFP, $\mathrm{CreER}^{\mathrm{T} 2}$, and $\mathrm{ER}^{\mathrm{T} 2} \mathrm{CreER}^{\mathrm{T} 2}$. CreGFP is a fusion of Cre to green fluorescence protein that enables visualization of Cre expression (Kobayashi et al. 2008). In CreER ${ }^{\mathrm{T} 2} \mathrm{Cre}$ is linked to a mutant form of the human estrogen receptor $\left(\mathrm{ER}^{\mathrm{T} 2}\right)$. $\mathrm{ER}^{\mathrm{T} 2}$ is not able to bind the natural ligand (17 $\beta$-estradiol) at physiological concentrations but can bind the synthetic ligand 4hydroxytamoxifen (tamoxifen). After exposure to tamoxifen $\mathrm{CreER}^{\mathrm{T} 2}$ moves from the cytoplasm to the nucleus, where it catalyzes recombination. This tamoxifen-dependent induction of recombination system allows spatiotemporal control of gene activity. It can be used to pulse label cells and then monitor the labeled cells overtime (reviewed in (Feil et al. 
2009)). However, the high background activity in some cases (Ronzaud et al. 2011) may limit its application. $\mathrm{ER}^{\mathrm{T} 2} \mathrm{CreER}^{\mathrm{T} 2}$, which places Cre between two $\mathrm{ER}^{\mathrm{T} 2}$ elements, is designed to overcome this limitation. It is reported that $\mathrm{ER}^{\mathrm{T} 2} \mathrm{CreER}^{\mathrm{T} 2}$ apparently has a tighter control of induction and thus a lower background activity than $\mathrm{CreER}^{\mathrm{T} 2}$ (Matsuda and Cepko 2007). Alternatively, lineage tracing can be done using doxycycline-dependent rtTA inducible system (Gunther et al. 2002).

Obviously, interpretation of in vivo lineage tracing data relies on the faithfulness of the Credriven reporters in recapitulating the expression pattern of the endogenous gene, whose promoter drives Cre or Cre derivatives. Addition of $\mathrm{ER}^{\mathrm{T} 2}$ or GFP to Cre may impact the expression pattern of Cre, leading to false positivity. Hence, a direct comparison of Cre or Cre-driven reporters such as RFP and LacZ with the immunofluorescence staining signal of the endogenous gene may help to demonstrate the faithfulness.

\section{3. Identification of $\mathrm{Six}^{+}$progenitor cells responsible for generation of the main body of nephrons}

Multiple in vivo lineage tracing mouse models relevant to renal biology have been developed including Six2-Cre mice (Kobayashi et al. 2008). Six2-Cre mice contain a BAC transgene carrying a Tet-off-eGFPCre (TGC) cassette; knock-in strains are available with $T G C$, $C r e E R^{T 2}$ and $e G F P C r e E R^{T 2}$ cassettes residing at the Six 2 initiation codon.

As a homeodomain family member, Six 2 is very important in the maintenance of the progenitor cell pool in the metanephric mesenchyme. Six 2 deficiency leads to early termination of nephrogenesis and loss of progenitor cells. Six2-expressing cells are multipotent, have self-renewal capacity, and directly contribute to the differentiation of the nephron main body, including podocytes, the proximal tubule, the loop of Henle, and the distal convoluted tubule, but not the collecting duct, stromal cells, and interstitial cells (Kobayashi et al. 2008). Like Six2, Cited1 is also uniquely expressed in the cap mesenchyme (Boyle et al. 2008). In Cited1-CreER ${ }^{T 2}$ BAC knock-in mice, Cited1 ${ }^{+}$ progenitor cells are also found to contribute to the nephron but not the collecting duct epithelium when traced by LacZ (Boyle et al. 2008). Most recently, lineage tracing with mice carrying an $e G F P C r e E R^{T 2}$ cassette inserted at the $\operatorname{Lgr} 5$ locus shows that Lgr5 is a marker of a more committed group of cells located with in the distal region of s-shaped nephrogenic bodies (Barker et al. 2012) that only give rise to the thick ascending limb of Henle's loop and the distal convoluted tubule.

\section{Molecular signals governing ureteric bud growth and branching}

The metanephric mesenchyme can induce ureteric bud growth and branching. Reciprocally, the ureteric bud is capable of inducing nephrogenesis (reviewed in (Krause et al. 2015)). Many different stimulating or inhibitory signals regulate this mutual induction.

\subsection{Gdnf/Ret-signaling}

The principal molecular pathway responsible for the outgrowth and branching of the ureteric bud involves glial cell-derived neurotrophic factor (Gdnf) secreted by the metanephric mesenchyme, and its Ret receptor in the ureteric bud (Little and McMahon 2012). Secreted 
Gdnf activates a Gfra 1/Ret receptor tyrosine kinase complex, initiating a signaling cascade that increases the expression of Ret receptor and induces the outgrowth of Ret positive cells from the Wolffian duct towards the Gdnf signal (Costantini and Kopan 2010). The signaling cascade also upregulates different ureteric bud tip target genes such as Etv4, Etv5, Met, Mmp1, Spry and Wnt11. However, only Etv4 and Etv 5 are essential for the ureteric bud outgrowth (Lu et al. 2009). Wnt11 is a member of the Wnt superfamily of secreted glycoproteins. Disruption of Wnt11 in mice led to defects in ureteric branching morphogenesis and consequent kidney hypoplasia (Majumdar et al. 2003). Hence, Gdnf acts as a chemotactic cue for the outgrowth of the ureteric bud toward the metanephric mesenchyme. It should be noted that many pathways including ERK MAP kinase, PI3K, and PLC $\gamma$ also activate Ret signals and contribute to common ureteric bud branching (Krause et al. 2015).

\subsection{Wnt signaling pathway}

The secreted lipid-modified signaling Wnt-glycoproteins (Wnt) are critical for organogenesis including the development of kidney. Wnt5a, $-5 b,-6,-9 b$ and -11 are expressed in the ureteric bud while Wnt $2 \mathrm{~b},-4$ and $-5 \mathrm{a}$ are present in the metanephric mesenchyme (Krause et al. 2015). Wnt 4 is synthesized in the condensing mesenchyme and the comma- and s-shaped bodies. It acts in an autocrine manner to maintain the induced metanephric mesenchyme and plays an important role in the epithelialization of condensed mesenchyme and nephrogenesis (Stark et al. 1994; Kispert et al. 1998). Wnt7b in the collecting duct epithelium is crucial for cortico-medullary axis formation (Yu et al. 2009). Wnt $9 \mathrm{~b}$ and Wnt11 released by the ureteric bud induce the metanephric mesenchyme to form cap mesenchyme as well as promote a mesenchyme-to-epithelial transition to generate the renal vesicles. As a ureteric bud-derived inducer of nephrogenesis, Wnt9b contributes to the development of the transient mesonephric and permanent metanephric tubules and the extension of the Müllerian duct. It is required for the initial inductive response in the metanephric mesenchyme, i.e., the formation of the pretubular aggregate (Carroll et al. 2005). Recently, Wnt5a has been added to the list of the members of Wnt family that participate in kidney development (Nishita et al. 2014). Together with its receptor or coreceptor Ror2, a member of the Ror family of receptor tyrosine kinases, Wnt5a activates a non-canonical Wnt signaling pathway and inhibits the canonical Wnt signaling pathway (Oishi et al. 2003). Disruption of Wnt signaling can cause abnormal embryo development. For example, Robinow syndrome is caused by a Wnt5a mutation. The symptoms of this rare skeletal dysplasia syndrome include dysmorphic features resembling a fetal face, renal and vertebral anomalies, short-limb dwarfism, and hypoplastic external genitalia in males (Roifman et al. 2015).

\subsection{Six1 and Sall1 signaling}

Homeobox protein Six 1 in the un-induced metanephric mesenchyme is critical for early kidney development. It is required for the expression of Sall1, a multi-zinc finger transcription factor. Sall1 is critical for the development of the metanehpros. Ablation of Six 1 results in a failure of ureteric bud invasion into the mesenchyme and subsequent apoptosis of the mesenchyme in mice (Xu et al. 2003). Mice with deficiency in Sall1 are 
characterized by a failure in ureteric bud outgrowth, renal agenesis or severe dysgenesis, and perinatal death (Nishinakamura et al. 2001).

\subsection{FGF Signaling}

Fibroblast growth factors (FGF) trigger a signal cascade through FGF receptors during early metanephric development. The two important receptors Fgfr1 and Fgfr2 are expressed in the metanephric mesenchyme and ureteric bud. Fgfr2 is presented in all parts of the Wolffian duct and is crucial for Wolffian duct maintenance (Okazawa et al. 2015). While single ablation of Fgfrl or Fgfr2 does not cause abnormal kidney development, the lack of both results in kidney agenesis (Poladia et al. 2006).

As a result of the integration of multiple pathways, the cap mesenchyme gives rise to diverse nephron epithelial segments while the ureteric bud differentiates into the collecting duct.

\section{Collecting duct development.}

The renal collecting duct system is made up of a series of ducts and tubules that interconnect the nephrons to the ureter. It plays an important role in regulation of fluid and electrolyte metabolism through excretion and reabsorption, processes regulated by the steroid hormone aldosterone and antidiuretic hormone vasopressin. The collecting duct system contains several components including the connecting tubules, cortical collecting ducts, and medullary collecting ducts (Berrout et al. 2014).

\section{1. Function and cellular composition of the collecting duct}

In the collecting duct, two functionally and morphologically distinct cells are present: PC and IC (Bagnis et al. 2001). The homeostatic balance of water, electrolytes, and acid-base is fine-tuned by the expression of many transporters in PC and IC (Roy et al. 2015). PC express apical epithelial $\mathrm{Na}^{+}$channel $(\mathrm{ENaC})$ and the water channel Aqp2 as well as the basolaterally-located water channels Aqp3 and Aqp4. Collectively, they mediate the water and sodium balance. Aqp2-positive cells are present in the connecting tubule, cortical collecting duct, outer medullary collecting duct, and inner medullary collecting duct. Consistent with their primary role in regulating the acid-base balance, IC express vacuolartype $\mathrm{H}^{+}$-ATPase (V-ATPase) and carbonic anhydrase II (CAII). V-ATPases acidify several intracellular organelles and pump protons across the plasma membranes in a wide array of cell types. Proton transport across intracellular and plasma membranes is coupled to ATP hydrolysis through V-ATPases. The carbonic anhydrases belong to a family of enzymes that catalyze the production of bicarbonate and protons from carbon dioxide and water. IC can be further divided into two types according to their immunological differences: $\mathrm{a}-\mathrm{IC}$ and $\beta$-IC. a-IC display V-ATPase at the apical membrane and anion exchanger 1 (AE1) at the basolateral membrane, which is responsible for secreting protons into the urine and reabsorbing bicarbonates, respectively (Roy et al. 2015).

Acidified urine can prevent bacterial growth and other urinary organisms. Nevertheless, acidification of urine rather than a dedicated role in preventing urinary tract infection has been assigned to $\mathrm{a}-\mathrm{IC}$. Recent studies have revealed a novel mechanism by which $\mathrm{a}-\mathrm{IC}$ function in the innate immune defense of urinary tract infection. $a$-IC produce and release 
neutrophil gelatinase-associated lipocalin to chelate the siderophore containing host iron to achieve bacteriostasis (Paragas et al. 2014; Chen and Zhang 2014; Becknell et al. 2015).

While $\beta$-IC mirror the polarity and function of $\mathrm{a}$-IC, they are characterized by the apical expression of pendrin that secretes bicarbonates, and the basolateral expression of V-ATPase that reabsorbs protons (Roy et al. 2015). In addition, Non-A, Non-B IC express both pendrin and V-ATPase at the apical side and likely secrete bicarbonates and protons (Roy et al. 2015).

Unlike the wide distribution of PC throughout the kidney, IC have a more restricted presence. $\mathrm{a}$-IC are found in connecting tubules, cortical collecting ducts, outer medulla collecting ducts and the initial part of inner medulla collecting ducts. $\beta$-IC are abundant only in connecting tubules and cortical collecting ducts (Roy et al. 2015). Besides these major transporters, other important channels are also found in the collecting duct cells like chloride/bicarbonate exchangers SLC26A7 and SLC26A11, AE4, and $\mathrm{Na}^{+} / \mathrm{K}^{+} \mathrm{ATPase}$ (Roy et al. 2015).

\section{2. Molecular regulators of collecting duct differentiation}

\section{2. 1. Circumferential evidence suggesting a common origin of $P C$ and IC.}

-Based on expression of PC and IC markers as well as functional characteristics, an early study shows that sorted PC in primary culture do not change their PC phenotype and are thus deemed as terminally differentiated cells. Unlike PC, $\beta$-IC differentiate into PC, $\alpha$-IC, and PC/IC "hybrids", a behavior of multipotent cells (Fejes-Toth and Naray-Fejes-Toth 1992). Consistently, metabolic acidosis decreases $\beta$-IC and increases $\alpha$-IC without changing the total IC population, indicating $\beta$-IC conversion to a-IC (Schwartz et al. 1985). Disruption of the extracellular matrix protein hensin/DMBT1 results in absence of typical a-IC in mice (Gao et al. 2010). Mice deficient in the forkhead transcription factor Foxil contain a single cell type (Aqp2 ${ }^{+} \mathrm{CAII}^{+}$) that has undetectable expression of other IC markers (V-ATPase B1, AE1, AE4, and Pendrin) in the cortex and medulla, arguing that PC and IC arise from progenitor cells characterized by Foxi1 ${ }^{-} \mathrm{Aqp}^{+}{ }^{+} \mathrm{CAII}^{+}$(Blomqvist et al. 2004). Analyses of IC markers AE1 and $\mathrm{H}^{+}$-ATPase expression in CAII knockout mice indicate that IC are severely diminished and replaced by PC (Breton et al. 1995).

Loss of Notch signaling results in an increase in the number of IC at the expense of PC. A disintegrin and metalloproteinase domain 10 (Adam10) is a member of the ADAM family of cell membrane-anchored proteins. Adam10 is involved in Notch and other signaling pathways. Inactivation of Adam10 in ureteric bud derivatives with a HoxB7-Cre driver leads to reduced PC and increased IC (Guo et al. 2015). A similar decrease of PC/IC ratio in the collecting ducts is observed in HoxB7-Cre Mib ${ }^{\text {f/f }}$ mice (Jeong et al. 2009). As an E3 ubiquitin protein ligase, Mib1 plays a key role in the Notch and Wnt/receptor-like tyrosine kinase signaling pathways. These changes in PC to IC ratios in the Notch collecting duct mutants, along with the known conserved role of Notch signaling in binary cell fate choices, is highly suggestive that these PC and IC differentiate from a common precursor cell type. Notch signaling likely plays a conserved role in the "salt and pepper" patterning of the collecting duct epithelium with intermingled cell types just as it does in other biological 
settings including drosophila imaginal discs, frog skin, lung epithelium, and zebrafish pronephros (Quigley et al. 2011; Janicke et al. 2007).

The $\mathrm{HoxB} 7-\mathrm{Cre}$ transgene permits Cre expression under the control of a $1.3 \mathrm{~kb}$ mouse homeobox B7 (HoxB7) enhancer and promoter. Cre-mediated activation of the ROSA reporter is visible in the mesonephric duct as early as E9.5, in the ureteric bud by E10.25, and in all ureteric bud epithelial cells by E12.5. Dorsal root ganglia and the spinal cord have low levels of Cre activity (Yu et al. 2002). Given the detection of the HoxB7-Cre activity specifically within the mesonephric duct and its derivatives (the Wolffian duct, the collecting duct and the ureteral epithelium), PC and IC may be differentiated from a pool of progenitor cells marked by HoxB7 expression. However, the faithfulness of the HoxB7-Cre transgene and expression of HoxB7 in IC remain obscure. This is because a direct comparison of Cre expression with the endogenous HoxB7, and co-expression of either the endogenous HoxB7 or Cre with IC markers, to our knowledge, have not been reported. Nevertheless, the HoxB7$C r e$ driver has been used to ablate multiple genes including sonic hedgehog, $a E N a C$, and Aqp2 as well as Adam10 and Mib1 in the collecting duct (Yu et al. 2002; Rubera et al. 2003; Rojek et al. 2006).

\section{2. 2. Dot1l as a primary epigenetic regulator of $E N a C$ in kidney-Disruptor}

of telomeric silencing (DotI) was originally identified in the yeast Saccharomyces cerevisiae as a gene regulating telomeric silencing (Singer et al. 1998). Dot 1 and its mammalian homologs (Dot11) encode a unique family of methyltransferases specific for histone H3 K79 (Feng et al. 2002; van Leeuwen et al. 2002; Zhang et al. 2004). Unlike other methyltransferases, Dot1 and Dot11 do not contain a classical enhancer of zeste or trithorax domain (van Leeuwen et al. 2002). Dot1l is widely expressed and highly conserved and catalyzes the addition of one, two, or three methyl groups to lysine 79 at the global domain of histone H3 (Krogan et al. 2003; van Leeuwen et al. 2002; Wu et al. 2013). Dot11 functions in the regulation of transcription, development, erythropoiesis, differentiation, proliferation, and leukemogenesis (Chang et al. 2010; Jo et al. 2011; Okada et al. 2005). The global deletion of Dot 11 causes embryonic lethality (Jones et al. 2008).

Our previous studies on Dot11 function and regulation in renal physiology lead to 1) cloning of mouse Dot11 and identification of five alternative splicing variants (Dot1a-e) (Zhang et al. 2004); 2) demonstration of high Dot1l expression in mouse kidney and strong H3 di-methyl K79 (H3m2K79) staining in PC and IC (Zhang et al. 2006a; Zhang et al. 2004); 3) identification of Dot1a as an integral component of aldosterone signaling that regulates mRNA expression and activity of ENaC in mouse cortical collecting duct M1 cells and in mouse inner medulla collecting duct IMCD3 cells (Zhang et al. 2006a; Zhang et al. 2006b; Zhang et al. 2007; Chen et al. 2015); and 4) generation and characterization of Dot $1 f^{f / f}$ Aqp2Cre or Dot11 ${ }^{A C}$ mice (Chang et al. 2010; Wu et al. 2013; Xiao et al. 2015). In the Aqp2Cre transgene, Cre is inserted at the ATG of Aqp2 in a mouse genomic P1-derived artificial chromosome, which harbors a $125-\mathrm{kb} 5^{\prime}$ upstream region and a 31-kb $3^{\prime}$ downstream region of Aqp2. The Aqp2Cre driver mice carry two copies of the Aqp2Cre transgene and have been employed to inactivate $N R 3 C 2$ encoding mineralocorticoid receptor (MR) (Ronzaud et al. 2007). As predicted, Dot $11^{A C}$ vs. Dot $1^{f / f}$ mice had increased aENaC mRNA levels (Zhang et al. 2013). 
4. 2. 3. Derivation of IC from Aqp2 ${ }^{+}$progenitor cells in $D o t 1 A^{A C}$ mice-Dot $1 A^{A C}$ vs. $D o t t^{f / f}$ mice have $\sim 20 \%$ less PC and a similar percentage more IC. This change is associated with a significant increase in 24-h urine volume in the mutant mice, compared to the control mice. This change suggests a switch in cell fate in the absence of Dot11. Inactivation of Dot1l in PC completely abolishes mono-, di-, and tri-methylation at H3 K79. This finding not only indicates that Dot 11 is the sole enzyme for all methylation events at $\mathrm{H} 3$ $\mathrm{K} 79$, but also suggests that loss of $\mathrm{H} 3 \mathrm{~m} 2 \mathrm{~K} 79$ may be used to trace the Aqp2 ${ }^{+}$lineage in $\operatorname{Dot}^{A C}$ mice (Wu et al. 2013; Xiao et al. 2015).

Unexpectedly, Dot $11^{A C}$ mice also display undetectable $\mathrm{H} 3 \mathrm{~m} 2 \mathrm{~K} 79$ in $67-75 \%$ of IC identified by staining with an antibody recognizing V-ATPase B1 and B2 subunits (Figure 1) and in $84-90 \%$ of cells labeled by other 4 IC markers (V-ATPase A, CAII, AE1, and Pendrin). AE1 and Pendrin mark a-IC and $\beta$-IC, respectively (Wu et al. 2013).

Activation of the Aqp2Cre transgene may occur before the Aqp2 $2^{+}$progenitors switch to IC fate. As a result, Cre-dependent recombination leads to permanent inactivation of Dot11 and, thus, loss of H3m2K79 in the Aqp2 ${ }^{+}$lineage. However, Cre expressed in the Aqp2 ${ }^{+}$ progenitor cells will be eventually diluted out and the synthesis of new Cre molecules will be dependent on the Aqp2 promoter, which is active in PC and silenced in IC. As a result, detectable Cre should be observed only in Aqp2 ${ }^{+} \mathrm{PC}$ cells, but not in the Aqp2- $\mathrm{IC}^{+}$cells, if the Aqp2Cre is faithful. Alternatively, if the Aqp2Cre lacks faithfulness, it remains active to direct Cre expression in Aqp2- IC cells.

As predicted, Cre is exclusively expressed and readily detected in PC. However, Cre expression is undetectable in IC (Figure 2 and (Wu et al. 2013)). Hence, the lack of $\mathrm{H} 3 \mathrm{~m} 2 \mathrm{~K} 79$ in IC results from Cre expression before Aqp2 $2^{+}$progenitor cells switch to IC fate, rather than from promiscuous and constitutive Cre expression in IC. The exclusive detection of Cre expression in PC also suggests the faithfulness of the Aqp2Cre transgene. Hence, our study provides, for the first time, direct in vivo evidence showing that IC including both aIC and $\beta$-IC, as defined by existing standard markers, can be derived from Aqp2 ${ }^{+}$progenitor cells in Dot $11^{A C}$ mice. Derived IC can be found in the developing and adult kidneys. Inactivation of Dot 11 promotes this process, leading to increased IC/PC ratio and urine volume (Wu et al. 2013). Given expression of Aqp2 in some connecting tubule cells, it is possible that Aqp2 ${ }^{+}$progenitor cells may contribute to formation of the connecting tubule. This is consistent with the notion that the connecting tubule originates from the ureteric bud (Howie et al. 1993) or that the connecting tubule can be considered as hybrid epithelia generated by mutual induction from adjoining segments (Schmitt et al. 1999).

Nevertheless, three important questions remain. First, does the Aqp2Cre transgene truly recapitulate the spatial and temporal pattern of the endogenous Aqp2? Secondly, does IC derivation from $\mathrm{Aqp}^{+}$progenitor cells occur in normal physiological condition (i.e. with intact Dot1l function)? Thirdly, can the mature PC give rise to IC in adult kidney? These questions may be addressed by extensively characterizing the spatiotemporal faithfulness of the Aqp2Cre transgene and by generating an inducible $A q p 2 E R^{T 2} C r e E R^{T 2}$ knock-in model combined with the Cre-dependent RFP reporter. 


\section{Genetic diseases of collecting duct system}

As listed in Table 1, mutations or malfunctions of the channels, pumps, and transporters expressed in the collecting duct system have been observed and characterized in different human diseases (Roy et al. 2015; Bruce et al. 2000; Karet et al. 1999; Smith et al. 2000; Rossier and Schild 2008). Gain-of-function mutations in $\mathrm{ENaC}$ cause hypertension (Liddle's syndrome) while loss-of-function mutations in $\mathrm{ENaC}$ lead to hypotension (Pseudohypoaldosteronism type 1) (Rossier and Schild 2008; Roy et al. 2015). Mutations in either AE1 or V-ATPase cause a failure to acidify urine and decrease plasma bicarbonates, leading to distal renal tubular acidosis (Roy et al. 2015). Patients with mutations in AQP2 or $A V P R 2$, for example, develop nephrogenic diabetes insipidus (NDI), which is characterized by the inability to concentrate urine and excessive urine production. Thus, a better understanding of the function and development of the collecting duct may facilitate the discovery of new therapeutic strategies for kidney disease.

\section{1. Liddle's syndrome}

5. 1. 1. Clinical characteristics-The original family described by Liddle et al has early onset of severe salt-sensitive hypertension in multiple siblings (Liddle et al. 1963). Some of them also display hypokalemia, decreased plasma renin activity and negligible aldosterone secretion, even on a low-sodium diet (Liddle et al. 1963). These features exclude primary aldosteronism. Other clinical findings such as the high ratios of sodium to potassium in saliva and sweat, the ineffectiveness of spironolactone on electrolyte metabolism and high blood pressure, and normal urinary levels of glucocorticoid metabolites rule out excessive secretion or ingestion of other mineralocorticoids. While the patients on a low sodium diet do not respond to pharmacological challenges with MR inhibitors, prominent amelioration in both hypertension and hypokalemia are achieved through the use of triamterene, a specific $\mathrm{ENaC}$ inhibitor.

Renal failure is eventually developed in the proband woman of the original Liddle's kindred. After receiving a cadaveric renal transplant, her abnormalities in both blood pressure and serum potassium levels are corrected, with normal response of the renin-aldosterone axis to salt restriction (Botero-Velez et al. 1994).

Several independent studies (Rodriguez et al. 1981; Wang et al. 1981; Nakada et al. 1987) have confirmed the original Liddle's description (Liddle et al. 1963), and showed that the effective treatments are triamterene and amiloride, but not spironolactone, for hypertension and hypokalemia in Liddle's patients as long as they have restricted dietary $\mathrm{Na}^{+}$intake. The disease exists worldwide, without predilection for any race or either sex. Affected pedigrees have been documented in USA (Shimkets et al. 1994), Japan (Inoue et al. 1998; Uehara et al. 1998), Sweden (Melander et al. 1998), French (Jeunemaitre et al. 1997), UK (Jackson et al. 1998), China (Gao et al. 2013), Thailand (Sawathiparnich et al. 2009), and African (Rayner et al. 2003).

5. 1. 2. Genetic basis of Liddle's syndrome-The extended pedigree of the proband in the original Liddle's kindred clearly demonstrates autosomal dominant inheritance. Hypertension associated with hypokalemia indicates that the high blood pressure might 
result from excessive $\mathrm{Na}^{+}$reabsorption in the distal nephron, where $\mathrm{Na}^{+}$reabsorption through the amiloride-sensitive, aldosterone-regulated, $\mathrm{ENaC}$ is indirectly linked to $\mathrm{K}^{+}$ secretion. Mapping analyses of the original Liddle's kindred demonstrate complete linkage of the disease to $S C N N 1 B$, the gene encoding $\beta E N a C$ on chromosome 16. Molecular analysis of $S C N N 1 B$ leads to identification of a premature stop codon, which truncates the cytoplasmic $\mathrm{C}$-terminus of $\beta \mathrm{ENaC}$ in the affected subjects. Frameshift mutations as well as premature termination in this same $\mathrm{C}$-terminal domain have been found in all affected subjects from four additional kindreds with Liddle's syndrome (Shimkets et al. 1994). Liddle's syndrome can also arise from a mutation ablating the C-terminus of $\gamma \mathrm{ENaC}$ encoded by $S C N N 1 G$ (Hansson et al. 1995a). Currently, over 20 mutations in $S C N N 1 B$ and $S C N N 1 G$ have been identified to cause Liddle's syndrome (reviewed in (Yang et al. 2014)). These findings collectively demonstrate gain-of-function mutations in the genes encoding $\beta$ and $\gamma \mathrm{ENaC}$ as the molecular defects of Liddle's syndrome, and highlight the genetic heterogeneity of the disease.

\section{1. 3. Structure and function of $\mathbf{E N a C}-\mathrm{ENaC}$ belongs to epithelial sodium} channel/degenerin family of ion channels. It resides at the apical membrane of epithelia in multiple tissues such as lung, exocrine glands, colon, and distal nephron. The channel plays a critical role in the regulation of sodium transport in the collecting duct and hence sodium balance and blood pressure control. The significance of ENaC-mediated $\mathrm{Na}^{+}$transport has been dramatically illustrated by the fact that Liddle's syndrome and pseudohypoaldosteronism type 1 (see below) have been linked to gain-of-function and lossof-function mutations, respectively, in the genes encoding the $\mathrm{ENaC}$ subunits.

ENaC consists of three homologous subunits, $a, \beta$, and $\gamma$ (Canessa et al. 1994), which are assembled with a stoichiometry of $2 a, 1 \beta, 1 \gamma$ (Firsov et al. 1998). Each subunit possesses short intracellular N- and C-termini, a large extracellular loop, and two transmembrane domains (Snyder et al. 1994). Highly conserved proline-rich domains, including the PY motif (xPPxY) appear in the C-terminal region of each subunit (Snyder et al. 1995). The importance of this C-terminal region in the pathogenesis of Liddle's syndrome is well established. As discussed above, all of the original mutations leading to premature stop codons and frameshift identified to spawn Liddle's syndrome result in removal of the Cterminus, with ablation of the PY motifs of $\beta$ - or $\gamma$-ENaC (Shimkets et al. 1994; Hansson et al. 1995a). Furthermore, some cases are caused by specific point mutations within the PY motif (Hansson et al. 1995b; Inoue et al. 1998), indicating this region as a critical site for $\mathrm{ENaC}$ regulation and as a "hot spot" of the disorder.

5. 1. 4. Molecular mechanism of Liddle's syndrome-Studies on the molecular mechanism by which Liddle's mutations of $\beta$ - or $\gamma$-ENaC alter the channel function lead to identification of a conserved motif in the $\mathrm{C}$ terminus of all $3 \mathrm{ENaC}$ subunits (Snyder et al. 1995). Loss of the $\mathrm{C}$-terminus of $\beta$ - or $\gamma$-ENaC can cause an increase in amiloride-sensitive $\mathrm{Na}^{+}$current. The elevated ENaC activity is not a result of an increase in the conductance of $\mathrm{Na}^{+}$through each channel or in the open probability (PO), the proportion of time that each channel is in the open state. Instead, the Liddle's truncations increase the number of active channels in the plasma membrane. Moreover, both the truncation of the $\mathrm{C}$ terminus and the 
mutation of the highly conserved C-terminal motif elevate surface abundance of hybrid proteins possessing the $C$ terminus of the $\beta$ subunit (Snyder et al. 1995). Therefore, by eliminating a conserved motif, mutations in the Liddle's syndrome increase the apical location of $\mathrm{Na}^{+}$channels, leading to an increase in renal $\mathrm{Na}^{+}$reabsorption and a predisposition to hypertension. In other words, increase in $\mathrm{ENaC}$ activity with increase in renal $\mathrm{Na}^{+}$reabsorption in the collecting duct is considered as the primary cause of hypertension in Liddle's syndrome.

The ubiquitin-protein ligase Nedd4 interacts with the PY motifs of either $\beta$ - or $\gamma$-ENaC and ubiquitination regulates ENaC (Staub et al. 1996; Staub et al. 1997). Overexpression of wild type Nedd4, together with $\mathrm{ENaC}$, can reduce the channel activity in Xenopus oocytes. In contrast, overexpression of a catalytically inactive Nedd 4 can stimulate the ENaC activity, possibly by serving as a competitive antagonist to the endogenous Nedd4. Nedd4-mediated alternations in the channel activity are not observed in ENaC lacking the PY motifs, indicating the dependency of the Nedd4-mediated inhibition of ENaC on the C-terminal PY motifs. The alteration in the channel activity is attributable entirely to the change in the channel number at the plasma membrane (Abriel et al. 1999). These studies suggest that Nedd4 negatively regulates $\mathrm{ENaC}$ and that loss of Nedd4 binding sites in $\mathrm{ENaC}$ found in Liddle's syndrome might account for the increased channel number at the cell surface, the increased $\mathrm{Na}^{+}$resorption by the collecting duct, and hence hypertension. While the increased channel number at the cell surface probably results from changes in proteinprotein interactions regulating the channel degradation through Nedd4 (Staub et al. 1996; Abriel et al. 1999), the hyperactivity of the channel can also be achieved by Liddle's mutations through impairing the clathrin-dependent endocytosis of ENaC (Shimkets et al. 1997). Phosphorylation of Nedd4 by Sgk1 adds another layer of regulation since such modification decreases the affinity of Nedd4 towards ENaC (Bhalla et al. 2005;

Debonneville et al. 2001). Consequently, ENaC becomes less ubiquitinated, leading to the accumulation of $\mathrm{ENaC}$ channels in the cell surface. In addition, $\mathrm{ENaC}$ is tightly regulated at multiple levels by other various mechanisms including Dot1a-Af9-Af17-Sgk1-mediated transcription regulation (reviewed in (Chen et al. 2015; Soundararajan et al. 2012)).

5. 1. 5. Animal Models of Liddle's syndrome-To generate a mouse model mimicking the human Liddle's syndrome, Cre/loxP-mediated recombination is used as a gene replacement strategy (Pradervand et al. 1999). In this model, a Liddle's allele (L) is generated by introducing a stop codon in the mouse $S C N N 1 B$ locus, imitating human $\beta R 566 X$ identified in the original Liddle's kindred. Under normal salt intake, the heterozygotes $(\mathrm{L} /+)$ and homozygotes $(\mathrm{L} / \mathrm{L})$ at the age of 3 months display no developmental defects. While these mice have increased $\mathrm{Na}^{+}$reabsorption in distal colon and low plasma aldosterone, suggesting chronic hypervolemia, their blood pressure is not significantly different from that in WT mice. When challenged with a high salt diet, the Liddle mice develop hypertension, hypokalemia, and metabolic alkalosis associated with cardiac and renal hypertrophy. Hence, the Liddle mouse model replicates to a large extent Liddle's syndrome and establishes $\beta$ R566X mutation as the cause of the disease.

Analyses of the renal $\mathrm{Na}^{+}$transport in vivo, ex vivo with intact perfused tubules, and in vitro using primary culture of the cortical collecting ducts from the Liddle's mice consistently 
show the constitutive hyperactivity of ENaC (Pradervand et al. 2003). The cortical collecting ducts of $\mathrm{L} / \mathrm{L}$ mice under a low salt diet have the highest current (ENaC activity), as measured by patch clamp (Dahlmann et al. 2003). Conforming to the proposed pathogenic and molecular mechanism for the Liddle's mutation, the increase in whole cell current is attributed to an increase in the density of conducting channels (Dahlmann et al. 2003).

Despite a primary renal mechanism of Liddle's syndrome, dysregulation of ENaC in other tissues may also be involved. Endothelial cells from the Liddle's mice have enhanced cortical stiffness and ENaC expression (Jeggle et al. 2013). Since the vascular endothelium plays a key role in the control of vascular tone, it is possible that $\mathrm{ENaC}$ in the vascular endothelia regulates cellular mechanics and hence plays a role in the control of vascular function (Jeggle et al. 2013). In addition, $\mathrm{ENaC}$-mediated $\mathrm{Na}^{+}$transport is enhanced with an increased responsiveness to aldosterone in the colon of Liddle mice. This may be of pathophysiological relevance in subjects with Liddle's syndrome, in particular under a high salt diet, when suppression of aldosterone is not likely to be sufficient to decrease $\mathrm{Na}^{+}$ absorption to an appropriate level (Nesterov et al. 2012). The pathology of Liddle's syndrome might, hence, relate to $\mathrm{ENaC}$ dysfunction not only in the kidney, but also in other tissues such as the vascular endothelia and colon.

5. 1. 6. Genetic testing of Liddle's syndrome-Traditionally, Liddle's syndrome is diagnosed on the basis of clinical characteristics that may overlap with other Mendelian forms of hypertension. Furthermore, factors including the mild phenotype, atypical cases, and the presence of hypertension without a family history, make an accurate diagnosis much more difficult. The variability in the severity of hypertension and hypokalemia in this disease raises the possibility that this disease may be underdiagnosed, particularly among patients with essential hypertension. While several functional tests to determine the response to MR inhibitors vs. ENaC inhibitors, or aldosterone response to cosyntropin may facilitate the diagnosis, they are time-consuming and inaccurate. Identification of Liddle's syndrome as a monogenic disorder makes it possible for genetic testing and counseling. To date, over 20 Liddle's mutations have been identified in the exon 13 of $S C N N 1 B$ or $S C N N 1 G$ (reviewed in (Yang et al. 2014)). Most of these mutations are clustered in a very short region of the C-termini of either $\beta$ - or $\gamma \mathrm{ENaC}$. Therefore, direct DNA sequencing of exon 13 of both $S C N N 1 B$ and $S C N N 1 G$ may be exploited to develop a quick, sensitive, and specific genetic screening test for this disorder (Yang et al. 2014).

Family screening is one of the biggest advantages of genetic testing. Through family screening based on the index case, clinicians can identify individuals with potential Liddle's syndrome. Such individuals may be asymptomatic carriers who harbor a known family or de novo mutation. Once diagnosis of Liddle's syndrome is well-established, it offers subjects the possibility to avoid or delay severe complications. Subjects with symptoms can receive tailored therapy containing $\mathrm{ENaC}$ antagonists such as amiloride. Early interventions can also be applied to asymptomatic carriers of pathogenic mutations. While the results of a genetic test alone are not deterministic, genetic risk assessment can assist asymptomatic individuals to achieve better prognosis and change their life style, such as decreasing salt intake. Several groups have reported prospective genetic diagnosis of Liddle's syndrome in extended 
pedigrees, enabling unbiased assessment of the clinical manifestations due to the diseasecausing mutations (Findling et al. 1997; Wang et al. 2015).

Genetic testing of exon 13 of both $S C N N 1 B$ and $S C N N 1 G$ led to identification of 5 pathogenic mutations associated with Liddle's syndrome in 5 index patients and 12 of their relatives from a total of 330 young hypertensive subjects of 14 to 40 years old (Wang et al. 2015). They are nonsense, missense, and frameshift mutations, altering or truncating the conserved PY motif of $\beta$ - and $\gamma \mathrm{ENaC}$. These Liddle's patients have an earlier onset of hypertension, a stronger family history of hypertension, and higher blood pressure than those with essential hypertension. Hence, Liddle's syndrome is a significant etiology of hypertension in this young population (Wang et al. 2015). Genetic testing should be considered in young subjects with early onset of hypertension, particularly those with unknown causes of increased blood pressure and low levels of potassium and renin in blood.

\section{2. Pseudohypoaldosteronism type 1}

5. 2. 1. Clinical characteristics-The name of pseudohypoaldosteronism type 1 (PHA1) comes from its clinical features, which simulate low levels of aldosterone that regulates sodium reabsorption. However, patients with PHA1 possess high levels of aldosterone.

Based on the severity, the genes involved, and the pattern of inheritance, PHA1 can be divided into two types: autosomal recessive PHA1 (also known as generalized or systemic PHA1, arPHA1) and autosomal dominant PHA1 (also named as renal PHA1, adPHA1). arPHA1 is characterized by $\mathrm{Na}^{+}$loss from the kidneys, the sweat glands, the salivary glands, the colon, and other organs. The disease is more severe and does not get better with age. Patients with adPHA1 are presented with excessive $\mathrm{Na}^{+}$loss from the kidneys. The condition is relatively mild and often improves in early childhood.

Excessive $\mathrm{Na}^{+}$loss leads to hyponatremia and hyperkalemia. Infants with PHA1 can also suffer from metabolic acidosis. Hyponatremia, hyperkalemia, or metabolic acidosis can induce nonspecific symptoms including muscle weakness, vomiting, nausea, and fatigue in infants with PHA1.

The involvement of multiple organs in infants with arPHA1 causes additional signs and symptoms including lesions on the skin, cardiac arrhythmia, and recurrent lung infections. These conditions usually do not develop in adults with arPHA1 (Geller et al. 1998). PHA1 is a rare condition and affects 1 in 80,000 newborns.

5. 2. 2. Molecular genetics of PHA1-Loss-of-function mutations in one of 4 different genes involved in $\mathrm{Na}^{+}$metabolism cause arPHA1 or adPHA1. Affected subjects in 5 families with arPHA1 are homozygous for mutations in either $S C N N 1 A$ or $S C N N 1 B$, which encode $\alpha$ - and $\beta E N a C$, respectively (Chang et al. 1996). A 3' splice site mutation in $S C N N 1 G$ identified in 3 families with arPHA1 causes abnormal splicing, generating 2 splicing variants. One variant arises from skipping the downstream exon and the other from activation of an adjacent cryptic splice site (Strautnieks et al. 1996). Unlike those in Liddle's syndrome, all of these $\mathrm{ENaC}$ mutations cause premature termination, missense mutations, or 
frameshift that lead to loss of the channel activity. Loss-of-function mutations of $\mathrm{ENaC}$ are thus causative of arPHA1.

Mutations in NR3C2, which encodes MR, result in adPHA1. In 6 dominant and 7 sporadic PHA1 kindreds screened, the affected individuals of 4 adPHA1 kindreds and one sporadic case have heterozygous $N R 3 C 2$ mutations and lack mutations in $\mathrm{ENaC}$ genes. These $N R 3 C 2$ mutations include 2 frameshift mutations, 2 premature termination codons, and one splice donor mutation. They co-segregate with PHA1 and are absent in unaffected subjects (Geller et al. 1998).

Analyses of a Japanese family with adPHA1 lead to identification of a heterozygous point mutation L924P in all affected members. This mutation abolishes aldosterone response in reporter assays in COS- 1 cells, suggesting that the missense mutation in NR3C2 is responsible for the adPHA1 in this family (Tajima et al. 2000). Ins2871C in exon 9 of $N R 3 C 2$ of a sporadic case with adPHA1 results in a new frameshift mutation, altering the last 27 residues of the hormone-binding domain (Viemann et al. 2001).

In 14 kindreds with sporadic or adPHA1, there are 6 heterozygous $N R 3 C 2$ mutations, which impact MR structure and function differently (Sartorato et al. 2003). The DNA binding domain mutant G633R has decreased maximal transactivation. Q776R and L979P mutations in the ligand-binding domain abolish or reduce aldosterone binding and thus aldosteronedependent transactivation capacity, respectively. L979P also possesses a transdominant negative effect on WT MR function, while G633R and Q776R might induce haploinsufficiency. NR3C2 mutations are a common feature of adPHA1, being identified in $70 \%$ of the familial cases examined (Sartorato et al. 2003).

Among 6 heterozygous $N R 3 C 2$ mutations detected in 7 PHA1 patients from 6 unrelated families are 2 previously described frameshift mutations (c.1131dupT, and c.2871dupC), 2 novel nonsense mutations generating a truncated receptor protein, and 2 novel missense mutations (S818L and E972G) differently affecting MR function (Riepe et al. 2006). Since S818L mutant does not bind aldosterone, it neither translocates into the nucleus nor activates transcription. E972G mutant has a significantly decreased ligand-binding affinity and only 9\% of WT transcriptional activity (Riepe et al. 2006). Within 22 NR3C2 abnormalities in 33 patients with PHA1, $68 \%$ of the mutations are dominantly transmitted and $18 \%$ de novo mutations (Pujo et al. 2007). These findings collectively demonstrate that heterozygous NR3C2 mutations cause PHA1, highlight the critical role of MR function in regulating salt and blood pressure homeostasis in humans.

5. 2. 3. Mouse models of PHA1- $\mathrm{aENaC}(-/-)$ knockout mice are unable to clear fetal lung liquid at birth and die in early neonatal stage, excluding the evaluation of the PHA1 phenotype (Hummler et al. 1997). A transgene expressing aENaC under the control of a cytomegalovirus promoter in $\mathrm{aENaC}(-/-)$ knockout mice $[\mathrm{aENaC}(-/-) \mathrm{Tg}]$ can rescue the perinatal lethality and partially mend $\mathrm{Na}^{+}$transport in kidney, colon, and lung. $\mathrm{aENaC}(-/$ -)Tg mice develop clinical characteristics of severe PHA1 with metabolic acidosis, urinary salt-wasting, growth retardation, and $50 \%$ mortality by days 5-9. The PHA1 phenotype is compensated in adult aENaC(-/-)Tg survivors, with normal electrolyte and acid/base 
measurements but 6-fold higher plasma aldosterone than WT littermates (Hummler et al. 1997).

5. 2. 4. Genetic Testing of PHA1-While genetic testing for Liddle's syndrome can be focused on the C-terminals of $S C N N 1 B$ and $S C N N 1 G$, genetic testing for PHA1 is more expensive, requiring deletion/duplication analysis, targeted variant analysis, or even sequence analyses of the entire coding regions of 4 target genes: SCNN1A, SCNN1B, $S C N N 1 G$ and $N R 3 C 2$. Such tests have been available in multiple laboratories in Germany, Colombia, Spain, Portugal, and USA. A complete list of these laboratories can be found at http://www.ncbi.nlm.nih.gov/gtr/tests/? term=C1449842[DISCUI]\&test_type=Clinical\&display_string=Pseudohypoaldosteronism \%20type\%201\%20autosomal\%20dominant\&condition=C1449842.

\section{3. Distal renal tubular acidosis (dRTA)}

5. 3. 1. Clinical characteristics-As a rare genetic disorder, distal renal tubular acidosis (dRTA) arises from the failure of kidneys to acidify the urine normally. This disorder can be acquired or inherited. The clinical features of distal RTA include 1) hypokalemia; 2) normal anion gap metabolic acidosis/academia; 3) nephrocalcinosis due to calcium deposition in the kidney; 4) urinary stone formation related to low urinary citrate, hypercalciuria, and alkaline urine; and 5) bone demineralization causing rickets in children and osteomalacia in adults. These symptoms and sequelae of dRTA are inconstant. The entire clinical spectrum of the disease varies from being asymptomatic; to recurrent or persistent flank pain and hematuria from kidney stones, to severe rickets in childhood, growth impairment, progressive nerve deafness, renal failure, and even death (Laing et al. 2005). The disorder is frequently also manifested with sensorineural hearing loss (SNHL). The renal defect of dRTA lies at a-IC. In patients with dRTA, a-IC fails to secrete acid to acidify the urine. dRTA often causes $\mathrm{Na}^{+}$loss and volume contraction, leading to a compensatory increase in circulating aldosterone levels. Aldosterone promotes reabsorption of $\mathrm{Na}^{+}$and loss of $\mathrm{K}^{+}$in the collecting duct. The latter causes hypokalemia, a common feature of dRTA (reviewed in (Batlle and Haque 2012)).

5. 3. 2. Genetics of dRTA-To date, defects in three different genes have been demonstrated to be responsible for dRTA. These genes encode the components of the renal urinary acidification machinery. The first mutations responsible for dRTA are identified in SLC4A1, which encodes bicarbonate/chloride exchanger AE1, from patients with autosomal dominant dRTA (Bruce et al. 1997). All affected individuals in four kindreds are heterozygous for one of three SLC4A1 mutations (R589H, R589C, and S613F). None of these mutations are observed in any of 9 normal family members examined. The disease is co-segregated with a genetic marker close to SLC4A1 (Bruce et al. 1997).

Since no SLC4A1 mutations are found in the early studies of the families with autosomal recessive dRTA, SLC4A1 mutations are initially thought to always cause autosomal dominant dRTA (Bruce et al. 1997; Karet et al. 1998). However, this belief is overturned after the discovery of the association of SLC4A1 mutations with recessive dRTA (Choo et al. 2006; Khositseth et al. 2007). Both affected brother and sister in a Thai family are triply 
homozygous for two benign mutations M31T and K56E and for the loss-of-function mutation, G701D in AE1 (Choo et al. 2006).

Southeast Asian ovalocytosis (SAO) refers to a deletion of $S L C 4 A 1$, leading to ablation of AE1 residues 400-408 and hence erythrocyte abnormalities. In 3 Malaysian and 6 Papua New Guinean families with dRTA examined, SAO occurs in multiple families but does not itself cause dRTA (Bruce et al. 2000). Compound heterozygotes of each of 3 dRTA mutations (G701D; A858D; and $\triangle$ V850) with SAO all result in dRTA associated with abnormal red cell properties and hemolytic anemia. A858D is transmitted in a dominant manner while $\Delta \mathrm{V} 850$ and G701D show a pseudodominant phenotype when SAO allele is also present (Bruce et al. 2000).

Different compound heterozygous SLC4A1 mutations have been reported in 2 Thai families with recessive dRTA (Sritippayawan et al. 2004). The proband of the first family carries compound heterozygous G701D/S773P mutations, which are inherited from his clinically normal mother and father, respectively. In the second family, an affected brother and sister have dRTA and are compound heterozygotes for SAO and R602H mutations. The sister has only mild metabolic acidosis whereas her brother exhibits a severe form of dRTA, suggesting that other modifying factors or genes might regulate the severity of the disorder.

Defects in genes encoding V-ATPase B1 and a4 subunits: ATP6V1B1 and ATP6VOA4, are the genetic cause of recessive dRTA with and without SNHL, respectively (Karet et al. 1999; Smith et al. 2000; Stover et al. 2002; Vargas-Poussou et al. 2006). In 3 unrelated kindreds with dRTA with SNHL, the affected subjects have a homozygous point mutation that converts codon 31 of $A T P 6 B 1$ from CGA to TGA (i.e. R31X) (Karet et al. 1999).

In 26 autosomal recessive dRTA kindreds, $A T P 6 V 1 B 1$ mutations in 10 kindreds and $A T P 6 V 0 A 4$ mutations in 12 kindreds exist. The remaining 4 families lack linkage to ATP6V1B1 or ATP6VOA4. Several kindreds with mutations in ATP6VOA4 develop later onset of hearing loss than other dRTA families with progressive SNHL and mutations in ATP6V1B1 (Stover et al. 2002). These results suggested that dRTA with or without SNHL is the same disorder. In agreement with the associated hearing loss, both ATP6V1B1 and ATP6VOA4 are also expressed in the cochlea (Stover et al. 2002; Vargas-Poussou et al. 2006).

A brother and sister from a consanguineous Turkish kindred have an unusual coexistence of two separate recessive disorders: dRTA and osteopetrosis (Borthwick et al. 2003). The dRTA is a result of homozygosity for a G78R substitution in $A T P 6 V 1 B 1$, while the osteopetrosis is caused by a concurrent homozygous deletion in TCIRG1. TCIRG1 encodes an osteoclast specific isoform of V-ATPase subunit a (Borthwick et al. 2003). The exceptionality lies in two aspects. Firstly, the coinheritance of the two rare recessive disorders creates a phenocopy of CAII deficiency, offering a novel genetic explanation for the coexistence of osteopetrosis and dRTA; Secondly these disorders affect two different subunits of the VATPase that have opposite effects on bone density (Borthwick et al. 2003).

A Japanese family with dRTA associated with early onset of hearing loss possesses two novel ATP6V1B1 mutations: 15 base-pair deletion (c.756_770del) in exon 7 and 1 base-pair 
insertion (c.1242_1243insC) in exon 12. Both of these mutations are detected in a compound heterozygous state (Yashima et al. 2010). Presumably, mutations in any of genes encoding the at least 13 subunits of V-ATPase complex could cause dRTA, highlighting further genetic heterogeneity of the disorder.

5. 3. 3. Molecular mechanisms of dRTA-The molecular mechanisms of inherited dRTA are complex. The mutations may cause an array of defects ranging from internal sequestration of the mutated proteins in endoplasmic reticulum or Golgi apparatus to their mis-targeting to the plasma membrane.

AE1 R589C and S613F mutants have normal chloride transport activity in Xenopus oocytes (Bruce et al. 1997). These mutant proteins are also detected in erythrocytes and oocyte cell membranes, implying that they may be able to normally traffic to the surface of the a-IC of human kidney (Bruce et al. 1997). AE1 R589H mutant has impaired chloride transport activity. It causes a severe trafficking defect of the kidney kAE1 but not of erythrocyte AE1 in human embryonic kidney cells. Although functional, it is apparently trapped in the endoplasmic reticulum, rather than sorted to the basolateral membrane. Hence bicarbonate could not exit the cell (Bruce et al. 1997; Jarolim et al. 1998). Unlike the dominant R589H mutant, recessive kAE1 G701D and S773P mutants show normal localization to the basolateral membrane when co-expressed with WT kAE1. Glycophorin A is absolutely required for G701D mutant protein movement to the cell surface. Glycophorin A increases G701D surface expression, resulting in $100 \%$ return of transport activity to normal. This is suggested as an explanation for the absence of dRTA in heterozygous recessive patients (Bruce et al. 1997).

The $\Delta \mathrm{V} 850$ and $\mathrm{A} 858 \mathrm{D}$ mutant proteins have greatly decreased anion transport when expressed in red blood cells and Xenopus oocytes as compound heterozygotes $(\Delta \mathrm{V} 850 /$ A858D, $\Delta$ V850/SAO or A858D/SAO) (Bruce et al. 2000). The surface expression and the transport activity of $\Delta \mathrm{V} 850$ and $\mathrm{A} 858 \mathrm{D}$ mutants are only partially rescued by glycophorin $\mathrm{A}$. The dominant A858D mutant protein may be mis-targeted to an inappropriate plasma membrane domain in IC. The decreased anion transport activity may be the cause of dRTA in patients with the recessive $\Delta \mathrm{V} 850$ mutation (Bruce et al. 2000). The recessive mutation S667P also exhibits a similar glycophorin A rescue pattern. Glycophorin A is expressed in red blood cells but not in kidney cells. This could explain why kAE1 mutations rarely cause a red blood cell defect.

Since polarized MDCK cells are more representative of a-IC in the kidney than nonpolarized MDCK cells, they are used to define the underlying defects caused by AE1 mutations leading to dRTA (Cordat et al. 2006). These studies have uncovered several mechanisms by which AE1 mutations lead to reduced chloride-bicarbonate exchange activity and thus dRTA. For example, dominant R589H and S613F mutants are initially sequestered in the endoplasmic reticulum, and rapidly become barely detectable, possible due to degradation. The mutant proteins are also mis-targeted to the apical membrane in some cells. Recessive G701D is retained in the Golgi apparatus or sorted to the basolateral membrane to a lesser extent than the WT kAE1 (Cordat et al. 2006). In contrast, recessive AE1 S667P is sequestrated in the endoplasmic reticulum (Toye et al. 2008). Dominant 
M909T and G609R mutants are targeted to both the apical and basolateral membrane of polarized MDCK cells (Fry et al. 2012).

V-ATPase a4 G820R mutation abolishes phosphofructokinase-1 (PFK-1) binding to the mutant protein without affecting PFK-1 activity, and decreases proton transport by $78 \%$ and ATPase activity by $36 \%$ (Su et al. 2008). These data suggest that a4/PFK-1 binding is important for coupling the ATPase activity to proton transport.

WT V-ATPase B1, but none of its seven mutants (L81P, R124W, M174R, T275P, G316E, P346R, and G364S) examined are assembled into the multi-subunit V-ATPase, as demonstrated by co-immunoprecipitation in IMCD cells (Yang et al. 2006). The unassembled mutant subunits are sorted to the apical membrane. Such sorting is increased in response to acidic stimulation and impaired apical membrane abundance of the native VATPase. Therefore, B1 mutants may serve as antagonists of V-ATPase function by competing with the endogenous intact V-ATPase for the same apical trafficking pathway (Yang et al. 2006).

5. 3. 4. Mouse models of $d R T A-G e n e t i c$ ablation of various acid-base transporters leads to generation of mouse models of dRTA. These models reproduce some phenotypic features of human hereditary dRTA. Multiple clinical features observed in patients with $S C L 4 A 1$ mutations are similar to those in $S l c 4 a 1^{-1-}$ mice (Stehberger et al. 2007). Slc4a1 ${ }^{-1-}$ mice exhibit dRTA, characterized by hyperchloremic metabolic acidosis associated with inappropriately alkaline urine without bicarbonaturia, low net acid excretion, nephrocalcinosis, hyperphosphaturia, hypercalciuria, and hypocitraturia. Severe urinary concentration defect is also noted, which is evidenced by elevated blood osmolarity and low urine osmolarity, and could be attributed to dysregulated expression and localization of Aqp2 (Stehberger et al. 2007).

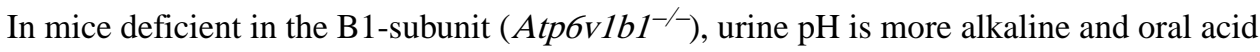
challenge worsens the metabolic acidosis, indicating impaired urinary acidification (Finberg

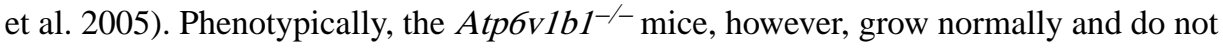
suffer from systemic acidosis on a normal rodent diet. Nephrocalcinosis, hypercalciuria, and any skeletal defects are not found, possibly due to the absence of metabolic acidosis development (Finberg et al. 2005). While the a4 subunit is also expressed in mice, knockout

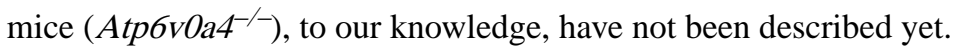

5. 3. 5. Genetic testing of $\mathbf{d R T A}-\mathrm{SNHL}$ is often seen in autosomal recessive $\mathrm{dRTA}$ caused by $A T P 6 V 1 B 1$ and $A T P 6 V O A 4$ mutations. By contrast, SCL $4 A 1$ mutations are not usually associated with any hearing loss (reviewed in (Batlle and Haque 2012)). This clinical distinguishing feature may be useful. Practically, mutations in ATP6V1B1 and ATP6VOA4 should be first suspected in dRTA associated with SNHL. However, although the presence of hearing loss and the type are considered as critical clues to the genetic defects underlying inherited dRTA, it is now becoming clearer that they are only helpful as an initial diagnostic impression. Since $<50 \%$ of the inherited RTA cases exhibit deafness and most of them might develop deafness later in life, genetic testing is left as the solely definitive tool in identifying the defects accurately and early in life. 


\section{4. Congenital nephrogenic diabetes insipidus}

5. 4. 1. Description-Diabetes insipidus consists of two major forms: central diabetes insipidus and nephrogenic diabetes insipidus (NDI). The former results from impaired hypothalamic-pituitary axis to produce or release sufficient amounts of vasopressin. The latter is caused by vasopressin insensitivity or hyporesponsiveness due to an intrinsic abnormality of the collecting duct. In both forms of the disorder, the failure of the kidney to concentrate the urine induces polyuria. NDI may be either acquired or congenital in origin. The acquired NDI is much more common than the congenital NDI. Various factors can cause acquired NDI. Chronic administration of the drug lithium is the major cause. Lithium seems to enter into the collecting duct PC through ENaC. ENaC-mediated lithium entry into PC contributes to the pathogenesis of lithium-induced NDI (Christensen et al. 2011). Among less common causes are hypokalemia, hypercalcemia, protein malnutrition, a variety of kidney diseases, and obstruction of the urinary tract (Khanna 2006).

5. 4. 2. Clinical findings-Patients with congenital NDI usually develop symptoms shortly after birth, with most infants being diagnosed within the first year of life. In addition to the main symptoms (polyuria, polydipsia and nocturia), the disorder may be associated with a wide range of other symptoms including vomiting, unexplained fevers, retching, irritability, lethargy, diarrhea, constipation, and poor feeding. Consequently, some affected individuals may fail to grow or gain weight at the expected rate. The severity of these symptoms varies from patient to patient. The chronic polyuria may lead to development of hydronephrosis, hydroureter, megacystis, and orthostatic hypotension in adult stage.

5. 4. 3. Genetics of congenital NDI-The inheritance of congenital NDI in most cases is $\mathrm{X}$-linked recessive, as first described in a Mormon family with 3 cases of male-to-male transmission of NDI. None of the females traced back to 1813 carries the disease (Cannon 1955). The disorder has now been linked to the defects in antidiuretic hormone arginine vasopressin receptor 2 gene ( $A V P R 2$ ) located on the long arm of the $\mathrm{X}$ chromosome (Xq28) (van den Ouweland et al. 1992). To date, more than 200 mutations in AVPR2 have been identified to cause NDI. Most of these mutations are missense mutations (Shida et al. 2013). Other types (i.e. nonsense mutations, insertions, deletions) are less frequent.

In rare cases, the disorder displays an autosomal recessive or dominant mode of inheritance. The recessive and dominant modes account approximately $10 \%$ and $1 \%$ of cases of hereditary NDI, respectively. In either case, the disease is caused by mutations of $A Q P 2$ on the long arm of chromosome 12 (12q13). Since the identification of a male NDI patient as a compound heterozygote for two $A Q P 2$ missense mutations (R187C and S217P) (Deen et al. 1994), forty-six putative disease-causing $A Q P 2$ mutations have been reported in 52 NDI families (reviewed in (Bichet et al. 2012)). In brief, inactivation of $A V P R 2$ and $A Q P 2$ is the molecular basis of congenital NDI.

5. 4. 4. AVPR2 and $A Q P 2-A V P R 2$ serves as the cognate $G$ protein-coupled receptor for arginine-vasopressin (AVP). It resides in the basolateral plasma membrane of PC. The binding of AVP to AVPR2 triggers a signaling cascade, resulting in activation of adenylyl cyclases AC3 and AC6 by the stimulatory G protein and thus conversion of ATP to cyclic 
adenosine monophosphate (cAMP). Protein kinase A (PKA) is one of the cAMP effectors. PKA holoenzyme is a tetramer of two regulatory subunits and two inactive catalytic subunits each bound to one regulatory subunit. There are four regulatory subunits (RIa, RI $\beta$, RIIa, $\mathrm{RII} \beta)$ and four catalytic subunits $(\mathrm{Ca}, \mathrm{C} \beta, \mathrm{C} \gamma$, Prkx) identified in mouse and human genomes. cAMP binds to the PKA regulatory subunits (two cAMP molecules per subunit), which results in release of the catalytic subunits from the tetramer. The free, and now active catalytic subunits act as serine-threonine kinases, phosphorylating numerous targets including AQP2.

Apical accumulation of AQP2 in PC increases the membrane permeability, permitting water to move down its osmotic gradient into the interstitium and enter the blood. AQP2 undertakes a constitutive recycling. It moves dynamically between its intracellular storage site and the plasma membrane under resting conditions. In response to AVP in an inadequate fluid status, the equilibrium is shifted toward plasma membrane insertion (Moeller et al. 2013). Subsequently, pro-urinary water reabsorption via coordinated action of AQP2 at the apical side and AQP3 and AQP4 at the basolateral membrane occurs to generate concentrated urine. This process is reversed by a reduction in circulating AVP levels, which reflects the establishment of isotonicity (Kim et al. 2005). AQP2 is under both short-term regulation and long-term regulation by AVP. The short-term regulation occurs in minutes by redistributing AQP2 from cell cytoplasm to cell membrane in response to AVP administration. The long-term regulation involves the transcriptional regulation of AQP2 (Boone and Deen 2008). Hence, redistribution of AQP2 between cell apical membrane and cell cytoplasm is the key for water reabsorption.

In the canonical pathway, regulation of AQP2 trafficking is mediated via AVP-AVPR2cAMP-PKA signaling as described above. PKA-catalyzed AQP2 phosphorylation on the cytoplasmic C-terminus (notably at S256) increases the rate of exocytosis (Brown 2003). Consistently, changes in cAMP levels and/or the activity of PKA by compounds such as calcitonin or prostaglandin E2 are translated into changes in AQP2 phosphorylation and trafficking (Bouley et al. 2011; Olesen et al. 2011).

S261, S264 and S269 in AQP2 have been identified as additional residues with phosphorylation states modulated by AVP (Hoffert et al. 2006; Hoffert et al. 2008). Emerging evidence suggests that phosphorylation at these residues can also affect AQP2 trafficking. S261 is de-phosphorylated in response to AVP treatment (Hoffert et al. 2007). pS261 is detected mainly in intracellular vesicles after ubiquitination and endocytosis, suggesting a potential role in stabilizing intracellular AQP2 (Hoffert et al. 2007). In contrast, pS269 has been found only on the plasma membrane (Hoffert et al. 2008) and may confer a resistance of AQP2 to endocytosis (Moeller et al. 2010). pS256 is not essential for AQP2 recycling, since AQP2-S256A recycles rapidly and constitutively. However, it is necessary for downstream phosphorylation of other C-terminal serines (Hoffert et al. 2008).

AVP-independent non-canonical pathways for AQP2 membrane accumulation have also been reported. Activation of protein kinase $\mathrm{G}$ (PKG) in response to increased cGMP can regulate phosphorylation of the AQP2 C-terminus (Bouley et al. 2005). Depolymerization of actin cytoskeleton can itself cause the membrane translocation of AQP2 in the absence of 
vasopressin (Klussmann et al. 2001). Modulation of endocytosis and/or exocytosis can impact the membrane accumulation of AQP2 (Brown 2003). Pharmacologically blocking endocytosis with statins (Wade 2011) or methyl- $\beta$-cyclodextrin (Russo et al. 2006) causes the redistribution of AQP2 on the plasma membrane independent of phosphorylation.

5. 4. 5. Molecular Mechanism - In vitro functional studies in Xenopus oocytes and in polarized renal tubular cells reveal that mutations in $A V P R 2$ might lead to: 1) impaired binding affinity of the receptor to the AVP, 2) mis-folding of the protein that is trapped intracellularly and unable to traffic to the cell membrane to interact with AVP, or 3) ineffectively transcribed AVPR 2 mRNAs (Fujiwara and Bichet 2005). Most of the AVPR2 mutations result in misfolded proteins (Hermosilla et al. 2004). These misfolded proteins likely accumulate in the Golgi compartment and subsequently degraded by ubiquitinproteasome system, resulting in loss-of-function phenotypes of AVPR2 unrelated to the actual function of the protein (Romisch 2004). Based on this hypothesis, strategies may be developed to rescue these functionally normal but misfolded proteins. The central idea is to promote the release of the trapped protein in the internal compartment of the cell. For example, the nonpeptide V2 and V1 receptor antagonists could severe as pharmacologic chaperons instead of endocytosis inhibitors to rescue the AVPR2 mutants (Morello et al. 2000). Patients with NDI treated with the vasopressin antagonist SR49059 have significantly decreased urine volume, water intake while other kidney functions like creatinine excretions, electrolytes levels remain constant (Bernier et al. 2006). These studies indicate that pharmacologic chaperons might have therapeutic implications for the treatment of several forms of NDI.

Most of the patients with autosomal recessive NDI have mutations throughout the six transmembrane domains and five connecting loops of AQP2. The AQP2 mutants fail to form tetramers with wild type AQP2. Similar to most of AVPR2 mutations, these recessive AQP2 mutations also lead to misfolded protein that are trapped in the endoplasmic reticulum and degraded by proteasome machinery (Boone and Deen 2008). Mutations in the autosomal dominant NDI are located in the C-terminal tail of AQP2. The general mechanism of this type of disease is the misrouting of the AQP2 because these mutants tetramerize with wild type AQP2 and reduce the plasma membrane expression of wild type AQP2 (Marr et al. 2002).

5. 4. 6. Animal models-The fortuitous finding of a laboratory rat with DI in Brattleboro, Vermont, USA, in 1961 has led to the development of a strain of rats with the disease. The Brattleboro rat has a deletion of a single base, guanine, in the AVP gene precursor coding region. The deletion causes a frameshift leading to the loss of the normal stop codon. The prolonged C-terminus impairs the folding and configuration necessary for normal processing of the AVP precursor in the endoplasmic reticulum. The mutated precursor is trapped in the endoplasmic reticulum and does not reach the Golgi apparatus. As a result, the rat has no detectable circulating AVP and displays central DI (Kim and Schrier 1998). It has become a very useful model to study the mechanism and treatment strategy of DI. 
Mouse models with a collecting duct specific or global deletion of $A q p 2$ are generated using the Cre/loxP technology (Rojek et al. 2006). To generate these NDI models, transgenic mice with loxP sites inserted into intron 2 and 3 of Aqp 2 are bred to the HoxB7-Cre driver (to generate collecting duct specific $\mathrm{KO}$ mice) or to mice expressing Cre recombinase under a globally expressed promoter. The mice with collecting duct specific deletion of Aqp2 survive with decreased urine osmolality and 10 times more urine, mimicking the severe phenotype of NDI. In contrast, mice with global deletion of Aqp2 die postnatally due to severe urine concentration defects (Rojek et al. 2006). These two NDI models highlight the importance of Aqp2 in controlling water balance and its unique role in the collecting duct. To mimic the recessive form of NDI, a knock-in mouse model is generated by replacing wild type Aqp2 with Aqp2-T216M (Yang et al. 2001). The mutants lack obvious abnormalities at 2-3 days after birth, but are unable to thrive and generally die by day 6 if supplemental fluid is not offered. A urinary concentrating defect is evidenced by low urine osmolality and serum hyperosmolality. Administration of a V2 vasopressin agonist fails to increase the urine osmolarity. Mutant kidneys show dilated collecting duct, atrophied papillary, and some Aqp2 staining at the plasma membrane. While WT Aqp2 displays complex glycosylation, Aqp2-T126M exhibits mainly endoglycosidase H-sensitive core glycosylation, indicating retention in the endoplasmic reticulum. Since the phosphorylation of Aqp2 by PKA is important for Aqp2 trafficking (Hoffert et al. 2006), a mouse model with S256L mutation is also created. This mutation results in a recessive NDI phenotype due to intracellular trapping of the mutated Aqp2 without apical sorting (McDill et al. 2006). Taken together, these studies suggest a critical role for Aqp2 in renal function in mice and establish multiple mouse models of human autosomal NDI.

\section{Reference}

Abriel H, Loffing J, Rebhun JF, Pratt JH, Schild L, Horisberger JD, Rotin D, Staub O (1999) Defective regulation of the epithelial Na+ channel by Nedd4 in Liddle's syndrome. The Journal of clinical investigation 103 (5):667-673. doi:10.1172/JCI5713 [PubMed: 10074483]

Bagnis C, Marshansky V, Breton S, Brown D (2001) Remodeling the cellular profile of collecting ducts by chronic carbonic anhydrase inhibition. American journal of physiology Renal physiology 280 (3):F437-448 [PubMed: 11181405]

Barker N, Rookmaaker MB, Kujala P, Ng A, Leushacke M, Snippert H, van de Wetering M, Tan S, Van Es JH, Huch M, Poulsom R, Verhaar MC, Peters PJ, Clevers H (2012) Lgr5(+ve) stem/ progenitor cells contribute to nephron formation during kidney development. Cell Rep 2 (3):540552. doi:10.1016/j.celrep.2012.08.018 [PubMed: 22999937]

Batlle D, Haque SK (2012) Genetic causes and mechanisms of distal renal tubular acidosis. Nephrology, dialysis, transplantation : official publication of the European Dialysis and Transplant Association - European Renal Association 27 (10):3691-3704. doi:10.1093/ndt/gfs442

Becknell B, Schwaderer A, Hains DS, Spencer JD (2015) Amplifying renal immunity: the role of antimicrobial peptides in pyelonephritis. Nature reviews Nephrology 11 (11):642-655. doi:10.1038/ nrneph.2015.105 [PubMed: 26149835]

Bernier V, Morello JP, Zarruk A, Debrand N, Salahpour A, Lonergan M, Arthus MF, Laperriere A, Brouard R, Bouvier M, Bichet DG (2006) Pharmacologic chaperones as a potential treatment for Xlinked nephrogenic diabetes insipidus. Journal of the American Society of Nephrology : JASN 17 (1):232-243. doi:10.1681/ASN.2005080854 [PubMed: 16319185]

Berrout J, Mamenko M, Zaika OL, Chen L, Zang W, Pochynyuk O, O’Neil RG (2014) Emerging role of the calcium-activated, small conductance, SK3 K+ channel in distal tubule function: regulation by TRPV4. PloS one 9 (4):e95149. doi:10.1371/journal.pone.0095149 [PubMed: 24762817] 
Bhalla V, Daidie D, Li H, Pao AC, LaGrange LP, Wang J, Vandewalle A, Stockand JD, Staub O, Pearce D (2005) Serum- and glucocorticoid-regulated kinase 1 regulates ubiquitin ligase neural precursor cell-expressed, developmentally down-regulated protein 4-2 by inducing interaction with 14-3-3. Mol Endocrinol 19 (12):3073-3084 [PubMed: 16099816]

Bichet DG, El Tarazi A, Matar J, Lussier Y, Arthus MF, Lonergan M, Bockenhauer D, Bissonnette P (2012) Aquaporin-2: new mutations responsible for autosomal-recessive nephrogenic diabetes insipidus-update and epidemiology. Clinical kidney journal 5 (3):195-202. doi:10.1093/ckj/sfs029 [PubMed: 26069764]

Blomqvist SR, Vidarsson H, Fitzgerald S, Johansson BR, Ollerstam A, Brown R, Persson AE, Bergstrom GG, Enerback S (2004) Distal renal tubular acidosis in mice that lack the forkhead transcription factor Foxi1. The Journal of clinical investigation 113 (11):1560-1570. doi:10.1172/ JCI20665 [PubMed: 15173882]

Boone M, Deen PM (2008) Physiology and pathophysiology of the vasopressin-regulated renal water reabsorption. Pflugers Archiv : European journal of physiology 456 (6):1005-1024. doi:10.1007/ s00424-008-0498-1 [PubMed: 18431594]

Borthwick KJ, Kandemir N, Topaloglu R, Kornak U, Bakkaloglu A, Yordam N, Ozen S, Mocan H, Shah GN, Sly WS, Karet FE (2003) A phenocopy of CAII deficiency: a novel genetic explanation for inherited infantile osteopetrosis with distal renal tubular acidosis. Journal of medical genetics 40 (2):115-121 [PubMed: 12566520]

Botero-Velez M, Curtis JJ, Warnock DG (1994) Brief report: Liddle's syndrome revisited--a disorder of sodium reabsorption in the distal tubule. The New England journal of medicine 330 (3):178181. doi:10.1056/NEJM199401203300305 [PubMed: 8264740]

Bouley R, Lu HA, Nunes P, Da Silva N, McLaughlin M, Chen Y, Brown D (2011) Calcitonin has a vasopressin-like effect on aquaporin-2 trafficking and urinary concentration. Journal of the American Society of Nephrology : JASN 22 (1):59-72. doi:10.1681/ASN.2009121267 [PubMed: 21071524]

Bouley R, Pastor-Soler N, Cohen O, McLaughlin M, Breton S, Brown D (2005) Stimulation of AQP2 membrane insertion in renal epithelial cells in vitro and in vivo by the cGMP phosphodiesterase inhibitor sildenafil citrate (Viagra). American journal of physiology Renal physiology 288 (6):F1103-1112. doi:10.1152/ajprenal.00337.2004 [PubMed: 15644488]

Boyle S, Misfeldt A, Chandler KJ, Deal KK, Southard-Smith EM, Mortlock DP, Baldwin HS, de Caestecker M (2008) Fate mapping using Cited1-CreERT2 mice demonstrates that the cap mesenchyme contains self-renewing progenitor cells and gives rise exclusively to nephronic epithelia. Developmental biology 313 (1):234-245. doi:10.1016/j.ydbio.2007.10.014 [PubMed: 18061157]

Breton S, Alper SL, Gluck SL, Sly WS, Barker JE, Brown D (1995) Depletion of intercalated cells from collecting ducts of carbonic anhydrase II-deficient (CAR2 null) mice. Am J Physiol 269 (6 Pt 2):F761-774 [PubMed: 8594870]

Brown D (2003) The ins and outs of aquaporin-2 trafficking. American journal of physiology Renal physiology 284 (5):F893-901. doi:10.1152/ajprenal.00387.2002 [PubMed: 12676734]

Bruce LJ, Cope DL, Jones GK, Schofield AE, Burley M, Povey S, Unwin RJ, Wrong O, Tanner MJ (1997) Familial distal renal tubular acidosis is associated with mutations in the red cell anion exchanger (Band 3, AE1) gene. The Journal of clinical investigation 100 (7):1693-1707. doi: 10.1172/JCI119694 [PubMed: 9312167]

Bruce LJ, Wrong O, Toye AM, Young MT, Ogle G, Ismail Z, Sinha AK, McMaster P, Hwaihwanje I, Nash GB, Hart S, Lavu E, Palmer R, Othman A, Unwin RJ, Tanner MJ (2000) Band 3 mutations, renal tubular acidosis and South-East Asian ovalocytosis in Malaysia and Papua New Guinea: loss of up to $95 \%$ band 3 transport in red cells. Biochem J 350 Pt 1:41-51 [PubMed: 10926824]

Canessa CM, Schild L, Buell G, Thorens B, Gautschi I, Horisberger JD, Rossier BC (1994) Amiloridesensitive epithelial $\mathrm{Na}+$ channel is made of three homologous subunits. Nature 367 (6462):463467. doi:10.1038/367463a0 [PubMed: 8107805]

Cannon JF (1955) Diabetes insipidus; clinical and experimental studies with consideration of genetic relationships. AMA archives of internal medicine 96 (2):215-272 [PubMed: 14397883]

Carroll TJ, Park JS, Hayashi S, Majumdar A, McMahon AP (2005) Wnt9b plays a central role in the regulation of mesenchymal to epithelial transitions underlying organogenesis of the mammalian 
urogenital system. Developmental cell 9 (2):283-292. doi:10.1016/j.devcel.2005.05.016 [PubMed: 16054034]

Chang MJ, Wu H, Achille NJ, Reisenauer MR, Chou CW, Zeleznik-Le NJ, Hemenway CS, Zhang W (2010) Histone H3 Lysine 79 Methyltransferase Dot1 Is Required for Immortalization by MLL Oncogenes. Cancer Res 70 (24):10234-10242. doi:70/24/10234 [pii] 10.1158/0008-5472.CAN-10-3294 [PubMed: 21159644]

Chang SS, Grunder S, Hanukoglu A, Rosler A, Mathew PM, Hanukoglu I, Schild L, Lu Y, Shimkets RA, Nelson-Williams C, Rossier BC, Lifton RP (1996) Mutations in subunits of the epithelial sodium channel cause salt wasting with hyperkalaemic acidosis, pseudohypoaldosteronism type 1 . Nature genetics 12 (3):248-253 [PubMed: 8589714]

Chen L, Zhang W (2014) Kidney a-Intercalated Cells, NGAL and Urinary Tract Infection. Austin J of Nephrology and Hypertension 1 (4):1017

Chen L, Zhang X, Zhang W (2015) Regulation of alphaENaC Transcription. Vitam Horm 98:101-135. doi:10.1016/bs.vh.2014.12.004 [PubMed: 25817867]

Choo KE, Nicoli TK, Bruce LJ, Tanner MJ, Ruiz-Linares A, Wrong OM (2006) Recessive distal renal tubular acidosis in Sarawak caused by AE1 mutations. Pediatric nephrology 21 (2):212-217. doi: 10.1007/s00467-005-2061-z [PubMed: 16252102]

Christensen BM, Zuber AM, Loffing J, Stehle JC, Deen PM, Rossier BC, Hummler E (2011) alphaENaC-mediated lithium absorption promotes nephrogenic diabetes insipidus. Journal of the American Society of Nephrology : JASN 22 (2):253-261. doi:10.1681/ASN.2010070734 [PubMed: 21051735]

Cordat E, Kittanakom S, Yenchitsomanus PT, Li J, Du K, Lukacs GL, Reithmeier RA (2006) Dominant and recessive distal renal tubular acidosis mutations of kidney anion exchanger 1 induce distinct trafficking defects in MDCK cells. Traffic 7 (2):117-128. doi:10.1111/j. 1600-0854.2005.00366.x [PubMed: 16420521]

Costantini F, Kopan R (2010) Patterning a complex organ: branching morphogenesis and nephron segmentation in kidney development. Developmental cell 18 (5):698-712. doi:10.1016/j.devcel. 2010.04.008 [PubMed: 20493806]

Dahlmann A, Pradervand S, Hummler E, Rossier BC, Frindt G, Palmer LG (2003) Mineralocorticoid regulation of epithelial $\mathrm{Na}+$ channels is maintained in a mouse model of Liddle's syndrome. American journal of physiology Renal physiology 285 (2):F310-318 [PubMed: 12684224]

Debonneville C, Flores SY, Kamynina E, Plant PJ, Tauxe C, Thomas MA, Munster C, Chraibi A, Pratt JH, Horisberger JD, Pearce D, Loffing J, Staub O (2001) Phosphorylation of Nedd4-2 by Sgk1 regulates epithelial $\mathrm{Na}(+)$ channel cell surface expression. The EMBO journal 20 (24):7052-7059 [PubMed: 11742982]

Deen PM, Verdijk MA, Knoers NV, Wieringa B, Monnens LA, van Os CH, van Oost BA (1994) Requirement of human renal water channel aquaporin-2 for vasopressin-dependent concentration of urine. Science 264 (5155):92-95 [PubMed: 8140421]

Feil S, Valtcheva N, Feil R (2009) Inducible Cre mice. Methods in molecular biology 530:343-363. doi:10.1007/978-1-59745-471-1_18 [PubMed: 19266339]

Fejes-Toth G, Naray-Fejes-Toth A (1992) Differentiation of renal beta-intercalated cells to alphaintercalated and principal cells in culture. Proceedings of the National Academy of Sciences of the United States of America 89 (12):5487-5491 [PubMed: 1608958]

Feng Q, Wang H, Ng HH, Erdjument-Bromage H, Tempst P, Struhl K, Zhang Y (2002) Methylation of H3-lysine 79 is mediated by a new family of HMTases without a SET domain. Curr Biol 12 (12): 1052-1058 [PubMed: 12123582]

Finberg KE, Wagner CA, Bailey MA, Paunescu TG, Breton S, Brown D, Giebisch G, Geibel JP, Lifton RP (2005) The B1-subunit of the $\mathrm{H}(+)$ ATPase is required for maximal urinary acidification. Proceedings of the National Academy of Sciences of the United States of America 102 (38): 13616-13621. doi:10.1073/pnas.0506769102 [PubMed: 16174750]

Findling JW, Raff H, Hansson JH, Lifton RP (1997) Liddle's syndrome: prospective genetic screening and suppressed aldosterone secretion in an extended kindred. The Journal of clinical endocrinology and metabolism 82 (4):1071-1074. doi:10.1210/jcem.82.4.3862 [PubMed: 9100575] 
Firsov D, Gautschi I, Merillat AM, Rossier BC, Schild L (1998) The heterotetrameric architecture of the epithelial sodium channel (ENaC). The EMBO journal 17 (2):344-352. doi:10.1093/emboj/ 17.2.344 [PubMed: 9430626]

Fry AC, Su Y, Yiu V, Cuthbert AW, Trachtman H, Karet Frankl FE (2012) Mutation conferring apicaltargeting motif on AE1 exchanger causes autosomal dominant distal RTA. Journal of the American Society of Nephrology : JASN 23 (7):1238-1249. doi:10.1681/ASN.2012020112 [PubMed: 22518001]

Fujiwara TM, Bichet DG (2005) Molecular biology of hereditary diabetes insipidus. Journal of the American Society of Nephrology : JASN 16 (10):2836-2846. doi:10.1681/ASN.2005040371 [PubMed: 16093448]

Gao L, Wang L, Liu Y, Zhou X, Hui R, Hu A (2013) A family with Liddle syndrome caused by a novel missense mutation in the PY motif of the beta-subunit of the epithelial sodium channel. The Journal of pediatrics 162 (1):166-170. doi:10.1016/j.jpeds.2012.06.017 [PubMed: 22809657]

Gao X, Eladari D, Leviel F, Tew BY, Miro-Julia C, Cheema F, Miller L, Nelson R, Paunescu TG, McKee M, Brown D, Al-Awqati Q (2010) Deletion of hensin/DMBT1 blocks conversion of \{beta\}- to \{alpha\}-intercalated cells and induces distal renal tubular acidosis. Proceedings of the National Academy of Sciences of the United States of America. doi:1010364107 [pii] 10.1073/ pnas. 1010364107

Geller DS, Rodriguez-Soriano J, Vallo Boado A, Schifter S, Bayer M, Chang SS, Lifton RP (1998) Mutations in the mineralocorticoid receptor gene cause autosomal dominant pseudohypoaldosteronism type I. Nature genetics 19 (3):279-281. doi:10.1038/966 [PubMed: 9662404]

Gunther EJ, Belka GK, Wertheim GB, Wang J, Hartman JL, Boxer RB, Chodosh LA (2002) A novel doxycycline-inducible system for the transgenic analysis of mammary gland biology. FASEB journal : official publication of the Federation of American Societies for Experimental Biology 16 (3):283-292. doi:10.1096/fj.01-0551com [PubMed: 11874978]

Guo Q, Wang Y, Tripathi P, Manda KR, Mukherjee M, Chaklader M, Austin PF, Surendran K, Chen F (2015) Adam10 mediates the choice between principal cells and intercalated cells in the kidney. Journal of the American Society of Nephrology : JASN 26 (1):149-159. doi:10.1681/ASN. 2013070764 [PubMed: 24904084]

Guyton AC, Hall JE (2006) Textbook of Medical Physiology.

Hansson JH, Nelson-Williams C, Suzuki H, Schild L, Shimkets R, Lu Y, Canessa C, Iwasaki T, Rossier B, Lifton RP (1995a) Hypertension caused by a truncated epithelial sodium channel gamma subunit: genetic heterogeneity of Liddle syndrome. Nature genetics 11 (1):76-82 [PubMed: 7550319]

Hansson JH, Schild L, Lu Y, Wilson TA, Gautschi I, Shimkets R, Nelson-Williams C, Rossier BC, Lifton RP (1995b) A de novo missense mutation of the beta subunit of the epithelial sodium channel causes hypertension and Liddle syndrome, identifying a proline-rich segment critical for regulation of channel activity. Proceedings of the National Academy of Sciences of the United States of America 92 (25):11495-11499 [PubMed: 8524790]

Hermosilla R, Oueslati M, Donalies U, Schonenberger E, Krause E, Oksche A, Rosenthal W, Schulein $\mathrm{R}$ (2004) Disease-causing V(2) vasopressin receptors are retained in different compartments of the early secretory pathway. Traffic 5 (12):993-1005. doi:10.1111/j.1600-0854.2004.00239.x [PubMed: 15522100]

Hoffert JD, Fenton RA, Moeller HB, Simons B, Tchapyjnikov D, McDill BW, Yu MJ, Pisitkun T, Chen F, Knepper MA (2008) Vasopressin-stimulated increase in phosphorylation at Ser269 potentiates plasma membrane retention of aquaporin-2. The Journal of biological chemistry 283 (36):24617-24627. doi:M803074200 [pii] 10.1074/jbc.M803074200 [PubMed: 18606813]

Hoffert JD, Nielsen J, Yu MJ, Pisitkun T, Schleicher SM, Nielsen S, Knepper MA (2007) Dynamics of aquaporin-2 serine-261 phosphorylation in response to short-term vasopressin treatment in collecting duct. American journal of physiology Renal physiology 292 (2):F691-700. doi: 00284.2006 [pii] 10.1152/ajprenal.00284.2006 [PubMed: 16985212]

Hoffert JD, Pisitkun T, Wang G, Shen RF, Knepper MA (2006) Quantitative phosphoproteomics of vasopressin-sensitive renal cells: regulation of aquaporin-2 phosphorylation at two sites. 
Proceedings of the National Academy of Sciences of the United States of America 103 (18):71597164. doi:10.1073/pnas.0600895103 [PubMed: 16641100]

Howie AJ, Smithson N, Rollason TP (1993) Reconsideration of the development of the distal tubule of the human kidney. J Anat 183 (Pt 1):141-147 [PubMed: 7505779]

Hummler E, Barker P, Talbot C, Wang Q, Verdumo C, Grubb B, Gatzy J, Burnier M, Horisberger JD, Beermann F, Boucher R, Rossier BC (1997) A mouse model for the renal salt-wasting syndrome pseudohypoaldosteronism. Proceedings of the National Academy of Sciences of the United States of America 94 (21):11710-11715 [PubMed: 9326675]

Humphreys BD, DiRocco DP (2014) Lineage-tracing methods and the kidney. Kidney international 86 (3):481-488. doi:10.1038/ki.2013.368 [PubMed: 24088959]

Humphreys BD, Lin SL, Kobayashi A, Hudson TE, Nowlin BT, Bonventre JV, Valerius MT, McMahon AP, Duffield JS (2010) Fate tracing reveals the pericyte and not epithelial origin of myofibroblasts in kidney fibrosis. Am J Pathol 176 (1):85-97. doi:10.2353/ajpath.2010.090517 [PubMed: 20008127]

Inoue J, Iwaoka T, Tokunaga H, Takamune K, Naomi S, Araki M, Takahama K, Yamaguchi K, Tomita K (1998) A family with Liddle's syndrome caused by a new missense mutation in the beta subunit of the epithelial sodium channel. The Journal of clinical endocrinology and metabolism 83 (6): 2210-2213. doi:10.1210/jcem.83.6.5030 [PubMed: 9626162]

Jackson SN, Williams B, Houtman P, Trembath RC (1998) The diagnosis of Liddle syndrome by identification of a mutation in the beta subunit of the epithelial sodium channel. Journal of medical genetics 35 (6):510-512 [PubMed: 9643296]

Janicke M, Carney TJ, Hammerschmidt M (2007) Foxi3 transcription factors and Notch signaling control the formation of skin ionocytes from epidermal precursors of the zebrafish embryo. Developmental biology 307 (2):258-271. doi:10.1016/j.ydbio.2007.04.044 [PubMed: 17555741]

Jarolim P, Shayakul C, Prabakaran D, Jiang L, Stuart-Tilley A, Rubin HL, Simova S, Zavadil J, Herrin JT, Brouillette J, Somers MJ, Seemanova E, Brugnara C, Guay-Woodford LM, Alper SL (1998) Autosomal dominant distal renal tubular acidosis is associated in three families with heterozygosity for the R589H mutation in the AE1 (band 3) Cl-/HCO3- exchanger. The Journal of biological chemistry 273 (11):6380-6388 [PubMed: 9497368]

Jeggle P, Callies C, Tarjus A, Fassot C, Fels J, Oberleithner H, Jaisser F, Kusche-Vihrog K (2013) Epithelial sodium channel stiffens the vascular endothelium in vitro and in Liddle mice. Hypertension 61 (5):1053-1059. doi:10.1161/HYPERTENSIONAHA.111.199455 [PubMed: 23460285]

Jeong HW, Jeon US, Koo BK, Kim WY, Im SK, Shin J, Cho Y, Kim J, Kong YY (2009) Inactivation of Notch signaling in the renal collecting duct causes nephrogenic diabetes insipidus in mice. The Journal of clinical investigation 119 (11):3290-3300. doi:10.1172/JCI38416 [PubMed: 19855135]

Jeunemaitre X, Bassilana F, Persu A, Dumont C, Champigny G, Lazdunski M, Corvol P, Barbry P (1997) Genotype-phenotype analysis of a newly discovered family with Liddle's syndrome. Journal of hypertension 15 (10):1091-1100 [PubMed: 9350583]

Jo SY, Granowicz EM, Maillard I, Thomas D, Hess JL (2011) Requirement for Dot11 in murine postnatal hematopoiesis and leukemogenesis by MLL translocation. Blood 117 (18):4759-4768. doi:blood-2010-12-327668 [pii]10.1182/blood-2010-12-327668 [PubMed: 21398221]

Jones B, Su H, Bhat A, Lei H, Bajko J, Hevi S, Baltus GA, Kadam S, Zhai H, Valdez R, Gonzalo S, Zhang Y, Li E, Chen T (2008) The histone H3K79 methyltransferase Dot1L is essential for mammalian development and heterochromatin structure. PLoS Genet 4 (9):1-11

Karet FE, Finberg KE, Nelson RD, Nayir A, Mocan H, Sanjad SA, Rodriguez-Soriano J, Santos F, Cremers CW, Di Pietro A, Hoffbrand BI, Winiarski J, Bakkaloglu A, Ozen S, Dusunsel R, Goodyer P, Hulton SA, Wu DK, Skvorak AB, Morton CC, Cunningham MJ, Jha V, Lifton RP (1999) Mutations in the gene encoding B1 subunit of H+-ATPase cause renal tubular acidosis with sensorineural deafness. Nature genetics 21 (1):84-90. doi:10.1038/5022 [PubMed: 9916796]

Karet FE, Gainza FJ, Gyory AZ, Unwin RJ, Wrong O, Tanner MJ, Nayir A, Alpay H, Santos F, Hulton SA, Bakkaloglu A, Ozen S, Cunningham MJ, di Pietro A, Walker WG, Lifton RP (1998) Mutations in the chloride-bicarbonate exchanger gene AE1 cause autosomal dominant but not autosomal recessive distal renal tubular acidosis. Proceedings of the National Academy of Sciences of the United States of America 95 (11):6337-6342 [PubMed: 9600966] 
Khanna A (2006) Acquired nephrogenic diabetes insipidus. Seminars in nephrology 26 (3):244-248. doi:10.1016/j.semnephrol.2006.03.004 [PubMed: 16713497]

Khositseth S, Sirikanerat A, Wongbenjarat K, Opastirakul S, Khoprasert S, Peuksungnern R, Wattanasirichaigoon D, Thongnoppakhun W, Viprakasit V, Yenchitsomanus PT (2007) Distal renal tubular acidosis associated with anion exchanger 1 mutations in children in Thailand. American journal of kidney diseases : the official journal of the National Kidney Foundation 49 (6):841-850 e841. doi:10.1053/j.ajkd.2007.03.002

Kim JK, Schrier RW (1998) Vasopressin processing defects in the Brattleboro rat: implications for hereditary central diabetes insipidus in humans? Proceedings of the Association of American Physicians 110 (5):380-386 [PubMed: 9756087]

Kim SW, Gresz V, Rojek A, Wang W, Verkman AS, Frokiaer J, Nielsen S (2005) Decreased expression of AQP2 and AQP4 water channels and Na,K-ATPase in kidney collecting duct in AQP3 null mice. Biology of the cell / under the auspices of the European Cell Biology Organization 97 (10): 765-778. doi:10.1042/BC20040148

Kispert A, Vainio S, McMahon AP (1998) Wnt-4 is a mesenchymal signal for epithelial transformation of metanephric mesenchyme in the developing kidney. Development 125 (21):4225-4234 [PubMed: 9753677]

Klussmann E, Tamma G, Lorenz D, Wiesner B, Maric K, Hofmann F, Aktories K, Valenti G, Rosenthal W (2001) An inhibitory role of Rho in the vasopressin-mediated translocation of aquaporin-2 into cell membranes of renal principal cells. The Journal of biological chemistry 276 (23):20451-20457. doi:10.1074/jbc.M010270200 [PubMed: 11278652]

Kobayashi A, Valerius MT, Mugford JW, Carroll TJ, Self M, Oliver G, McMahon AP (2008) Six2 defines and regulates a multipotent self-renewing nephron progenitor population throughout mammalian kidney development. Cell Stem Cell 3 (2):169-181. doi:10.1016/j.stem.2008.05.020 [PubMed: 18682239]

Krause M, Rak-Raszewska A, Pietila I, Quaggin SE, Vainio S (2015) Signaling during Kidney Development. Cells 4 (2):112-132. doi:10.3390/cells4020112 [PubMed: 25867084]

Krogan NJ, Dover J, Wood A, Schneider J, Heidt J, Boateng MA, Dean K, Ryan OW, Golshani A, Johnston M, Greenblatt JF, Shilatifard A (2003) The Paf1 complex is required for histone H3 methylation by COMPASS and Dot1p: linking transcriptional elongation to histone methylation. Mol Cell 11 (3):721-729 [PubMed: 12667454]

Laing CM, Toye AM, Capasso G, Unwin RJ (2005) Renal tubular acidosis: developments in our understanding of the molecular basis. The international journal of biochemistry \& cell biology 37 (6):1151-1161. doi:10.1016/j.biocel.2005.01.002 [PubMed: 15778079]

Liddle GW, Bledsoe T, Coppage WS Jr. (1963) A familial renal disorder simulating primary aldosteronism but with negligible aldosterone secretion. Trans Assoc Am Phys (76):199-213

Little MH, McMahon AP (2012) Mammalian kidney development: principles, progress, and projections. Cold Spring Harbor perspectives in biology 4 (5). doi:10.1101/cshperspect.a008300

Lu BC, Cebrian C, Chi X, Kuure S, Kuo R, Bates CM, Arber S, Hassell J, MacNeil L, Hoshi M, Jain S, Asai N, Takahashi M, Schmidt-Ott KM, Barasch J, D’Agati V, Costantini F (2009) Etv4 and Etv5 are required downstream of GDNF and Ret for kidney branching morphogenesis. Nature genetics 41 (12):1295-1302. doi:10.1038/ng.476 [PubMed: 19898483]

Madisen L, Zwingman TA, Sunkin SM, Oh SW, Zariwala HA, Gu H, Ng LL, Palmiter RD, Hawrylycz MJ, Jones AR, Lein ES, Zeng H (2010) A robust and high-throughput Cre reporting and characterization system for the whole mouse brain. Nat Neurosci 13 (1):133-140. doi:10.1038/nn. 2467 [PubMed: 20023653]

Majumdar A, Vainio S, Kispert A, McMahon J, McMahon AP (2003) Wnt11 and Ret/Gdnf pathways cooperate in regulating ureteric branching during metanephric kidney development. Development 130 (14):3175-3185 [PubMed: 12783789]

Marr N, Bichet DG, Lonergan M, Arthus MF, Jeck N, Seyberth HW, Rosenthal W, van Os CH, Oksche A, Deen PM (2002) Heteroligomerization of an Aquaporin-2 mutant with wild-type Aquaporin-2 and their misrouting to late endosomes/lysosomes explains dominant nephrogenic diabetes insipidus. Human molecular genetics 11 (7):779-789 [PubMed: 11929850] 
Matsuda T, Cepko CL (2007) Controlled expression of transgenes introduced by in vivo electroporation. Proceedings of the National Academy of Sciences of the United States of America 104 (3):1027-1032. doi:10.1073/pnas.0610155104 [PubMed: 17209010]

McDill BW, Li SZ, Kovach PA, Ding L, Chen F (2006) Congenital progressive hydronephrosis (cph) is caused by an S256L mutation in aquaporin-2 that affects its phosphorylation and apical membrane accumulation. Proceedings of the National Academy of Sciences of the United States of America 103 (18):6952-6957. doi:10.1073/pnas.0602087103 [PubMed: 16641094]

Melander O, Orho M, Fagerudd J, Bengtsson K, Groop PH, Mattiasson I, Groop L, Hulthen UL (1998) Mutations and variants of the epithelial sodium channel gene in Liddle's syndrome and primary hypertension. Hypertension 31 (5):1118-1124 [PubMed: 9576123]

Moeller HB, Praetorius J, Rutzler MR, Fenton RA (2010) Phosphorylation of aquaporin-2 regulates its endocytosis and protein-protein interactions. Proceedings of the National Academy of Sciences of the United States of America 107 (1):424-429. doi:10.1073/pnas.0910683107 [PubMed: 19966308]

Moeller HB, Rittig S, Fenton RA (2013) Nephrogenic diabetes insipidus: essential insights into the molecular background and potential therapies for treatment. Endocrine reviews 34 (2):278-301. doi:10.1210/er.2012-1044 [PubMed: 23360744]

Morello JP, Salahpour A, Laperriere A, Bernier V, Arthus MF, Lonergan M, Petaja-Repo U, Angers S, Morin D, Bichet DG, Bouvier M (2000) Pharmacological chaperones rescue cell-surface expression and function of misfolded V2 vasopressin receptor mutants. The Journal of clinical investigation 105 (7):887-895. doi:10.1172/JCI8688 [PubMed: 10749568]

Mugford JW, Sipila P, McMahon JA, McMahon AP (2008) Osr1 expression demarcates a multi-potent population of intermediate mesoderm that undergoes progressive restriction to an Osr1-dependent nephron progenitor compartment within the mammalian kidney. Developmental biology 324 (1): 88-98. doi:10.1016/j.ydbio.2008.09.010 [PubMed: 18835385]

Nagy A (2000) Cre recombinase: the universal reagent for genome tailoring. Genesis 26 (2):99-109 [PubMed: 10686599]

Nakada T, Koike H, Akiya T, Katayama T, Kawamata S, Takaya K, Shigematsu H (1987) Liddle's syndrome, an uncommon form of hyporeninemic hypoaldosteronism: functional and histopathological studies. The Journal of urology 137 (4):636-640 [PubMed: 3550146]

Nesterov V, Dahlmann A, Krueger B, Bertog M, Loffing J, Korbmacher C (2012) Aldosteronedependent and -independent regulation of the epithelial sodium channel $(\mathrm{ENaC})$ in mouse distal nephron. American journal of physiology Renal physiology 303 (9):F1289-1299. doi:10.1152/ ajprenal.00247.2012 [PubMed: 22933298]

Nishinakamura R, Matsumoto Y, Nakao K, Nakamura K, Sato A, Copeland NG, Gilbert DJ, Jenkins NA, Scully S, Lacey DL, Katsuki M, Asashima M, Yokota T (2001) Murine homolog of SALL1 is essential for ureteric bud invasion in kidney development. Development 128 (16):3105-3115 [PubMed: 11688560]

Nishita M, Qiao S, Miyamoto M, Okinaka Y, Yamada M, Hashimoto R, Iijima K, Otani H, Hartmann C, Nishinakamura R, Minami Y (2014) Role of Wnt5a-Ror2 signaling in morphogenesis of the metanephric mesenchyme during ureteric budding. Molecular and cellular biology 34 (16):30963105. doi:10.1128/MCB.00491-14 [PubMed: 24891614]

Oishi I, Suzuki H, Onishi N, Takada R, Kani S, Ohkawara B, Koshida I, Suzuki K, Yamada G, Schwabe GC, Mundlos S, Shibuya H, Takada S, Minami Y (2003) The receptor tyrosine kinase Ror2 is involved in non-canonical Wnt5a/JNK signalling pathway. Genes to cells : devoted to molecular \& cellular mechanisms 8 (7):645-654 [PubMed: 12839624]

Okada Y, Feng Q, Lin Y, Jiang Q, Li Y, Coffield VM, Su L, Xu G, Zhang Y (2005) hDOT1L links histone methylation to leukemogenesis. Cell 121 (2):167-178 [PubMed: 15851025]

Okazawa M, Murashima A, Harada M, Nakagata N, Noguchi M, Morimoto M, Kimura T, Ornitz DM, Yamada G (2015) Region-specific regulation of cell proliferation by FGF receptor signaling during the Wolffian duct development. Developmental biology 400 (1):139-147. doi:10.1016/ j.ydbio.2015.01.023 [PubMed: 25678108]

Olesen ET, Rutzler MR, Moeller HB, Praetorius HA, Fenton RA (2011) Vasopressin-independent targeting of aquaporin- 2 by selective E-prostanoid receptor agonists alleviates nephrogenic 
diabetes insipidus. Proceedings of the National Academy of Sciences of the United States of America 108 (31):12949-12954. doi:10.1073/pnas.1104691108 [PubMed: 21768374]

Paragas N, Kulkarni R, Werth M, Schmidt-Ott KM, Forster C, Deng R, Zhang Q, Singer E, Klose AD, Shen TH, Francis KP, Ray S, Vijayakumar S, Seward S, Bovino ME, Xu K, Takabe Y, Amaral FE, Mohan S, Wax R, Corbin K, Sanna-Cherchi S, Mori K, Johnson L, Nickolas T, D’Agati V, Lin CS, Qiu A, Al-Awqati Q, Ratner AJ, Barasch J (2014) alpha-Intercalated cells defend the urinary system from bacterial infection. The Journal of clinical investigation 124 (7):2963-2976. doi:10.1172/JCI71630 [PubMed: 24937428]

Poladia DP, Kish K, Kutay B, Hains D, Kegg H, Zhao H, Bates CM (2006) Role of fibroblast growth factor receptors 1 and 2 in the metanephric mesenchyme. Developmental biology 291 (2):325339. doi:10.1016/j.ydbio.2005.12.034 [PubMed: 16442091]

Pradervand S, Vandewalle A, Bens M, Gautschi I, Loffing J, Hummler E, Schild L, Rossier BC (2003) Dysfunction of the epithelial sodium channel expressed in the kidney of a mouse model for Liddle syndrome. Journal of the American Society of Nephrology : JASN 14 (9):2219-2228 [PubMed: 12937297]

Pradervand S, Wang Q, Burnier M, Beermann F, Horisberger JD, Hummler E, Rossier BC (1999) A mouse model for Liddle's syndrome. Journal of the American Society of Nephrology : JASN 10 (12):2527-2533 [PubMed: 10589691]

Pujo L, Fagart J, Gary F, Papadimitriou DT, Claes A, Jeunemaitre X, Zennaro MC (2007) Mineralocorticoid receptor mutations are the principal cause of renal type 1 pseudohypoaldosteronism. Human mutation 28 (1):33-40. doi:10.1002/humu.20371 [PubMed: 16972228]

Quigley IK, Stubbs JL, Kintner C (2011) Specification of ion transport cells in the Xenopus larval skin. Development 138 (4):705-714. doi:10.1242/dev.055699 [PubMed: 21266406]

Rayner BL, Owen EP, King JA, Soule SG, Vreede H, Opie LH, Marais D, Davidson JS (2003) A new mutation, R563Q, of the beta subunit of the epithelial sodium channel associated with low-renin, low-aldosterone hypertension. Journal of hypertension 21 (5):921-926. doi:10.1097/01.hjh. 0000059009.82022.9b [PubMed: 12714866]

Riepe FG, Finkeldei J, de Sanctis L, Einaudi S, Testa A, Karges B, Peter M, Viemann M, Grotzinger J, Sippell WG, Fejes-Toth G, Krone N (2006) Elucidating the underlying molecular pathogenesis of NR3C2 mutants causing autosomal dominant pseudohypoaldosteronism type 1 . The Journal of clinical endocrinology and metabolism 91 (11):4552-4561. doi:10.1210/jc.2006-1161 [PubMed: 16954160]

Rodriguez JA, Biglieri EG, Schambelan M (1981) Pseudohyperaldosteronism with renal tubular resistance to mineralocorticoid hormones. Transactions of the Association of American Physicians 94:172-182 [PubMed: 7046191]

Roifman M, Marcelis CL, Paton T, Marshall C, Silver R, Lohr JL, Yntema HG, Venselaar H, Kayserili H, van Bon B, Seaward G, Consortium FC, Brunner HG, Chitayat D (2015) De novo WNT5Aassociated autosomal dominant Robinow syndrome suggests specificity of genotype and phenotype. Clinical genetics 87 (1):34-41. doi:10.1111/cge.12401 [PubMed: 24716670]

Rojek A, Fuchtbauer EM, Kwon TH, Frokiaer J, Nielsen S (2006) Severe urinary concentrating defect in renal collecting duct-selective AQP2 conditional-knockout mice. Proceedings of the National Academy of Sciences of the United States of America 103 (15):6037-6042. doi:0511324103 [pii] 10.1073/pnas.0511324103 [PubMed: 16581908]

Romisch K (2004) A cure for traffic jams: small molecule chaperones in the endoplasmic reticulum. Traffic 5 (11):815-820. doi:10.1111/j.1600-0854.2004.00231.x [PubMed: 15479447]

Ronzaud C, Loffing J, Bleich M, Gretz N, Grone HJ, Schutz G, Berger S (2007) Impairment of sodium balance in mice deficient in renal principal cell mineralocorticoid receptor. Journal of the American Society of Nephrology : JASN 18 (6):1679-1687. doi:ASN.2006090975 [pii] 10.1681/ ASN.2006090975 [PubMed: 17475815]

Ronzaud C, Loffing J, Gretz N, Schutz G, Berger S (2011) Inducible renal principal cell-specific mineralocorticoid receptor gene inactivation in mice. American journal of physiology Renal physiology 300 (3):F756-760. doi:300/3/F756 [pii] 10.1152/ajprenal.00728.2009 [PubMed: 21383102] 
Rossier BC, Schild L (2008) Epithelial sodium channel: mendelian versus essential hypertension. Hypertension 52 (4):595-600. doi:10.1161/HYPERTENSIONAHA.107.097147 [PubMed: 18711011]

Roy A, Al-bataineh MM, Pastor-Soler NM (2015) Collecting duct intercalated cell function and regulation. Clinical journal of the American Society of Nephrology : CJASN 10 (2):305-324. doi:10.2215/CJN.08880914 [PubMed: 25632105]

Rubera I, Loffing J, Palmer LG, Frindt G, Fowler-Jaeger N, Sauter D, Carroll T, McMahon A, Hummler E, Rossier BC (2003) Collecting duct-specific gene inactivation of alphaENaC in the mouse kidney does not impair sodium and potassium balance. The Journal of clinical investigation 112 (4):554-565 [PubMed: 12925696]

Russo LM, McKee M, Brown D (2006) Methyl-beta-cyclodextrin induces vasopressin-independent apical accumulation of aquaporin-2 in the isolated, perfused rat kidney. American journal of physiology Renal physiology 291 (1):F246-253. doi:10.1152/ajprenal.00437.2005 [PubMed: 16449354]

Sartorato P, Lapeyraque AL, Armanini D, Kuhnle U, Khaldi Y, Salomon R, Abadie V, Di Battista E, Naselli A, Racine A, Bosio M, Caprio M, Poulet-Young V, Chabrolle JP, Niaudet P, De Gennes C, Lecornec MH, Poisson E, Fusco AM, Loli P, Lombes M, Zennaro MC (2003) Different inactivating mutations of the mineralocorticoid receptor in fourteen families affected by type I pseudohypoaldosteronism. The Journal of clinical endocrinology and metabolism 88 (6):25082517. doi:10.1210/jc.2002-021932 [PubMed: 12788847]

Sawathiparnich P, Sumboonnanonda A, Weerakulwattana P, Limwongse C (2009) A novel mutation in the beta-subunit of the epithelial sodium channel gene (SCNN1B) in a Thai family with Liddle's syndrome. Journal of pediatric endocrinology \& metabolism : JPEM 22 (1):85-89 [PubMed: 19344079]

Schmitt R, Ellison DH, Farman N, Rossier BC, Reilly RF, Reeves WB, Oberbaumer I, Tapp R, Bachmann S (1999) Developmental expression of sodium entry pathways in rat nephron. Am J Physiol 276 (3 Pt 2):F367-381 [PubMed: 10070160]

Schwartz GJ, Barasch J, Al-Awqati Q (1985) Plasticity of functional epithelial polarity. Nature 318 (6044):368-371 [PubMed: 2415824]

Shida Y, Matsuoka H, Chiga M, Uchida S, Sasaki S, Sugihara S (2013) Characterization of AQP-2 gene mutation (R254Q) in a family with dominant nephrogenic DI. Pediatrics international : official journal of the Japan Pediatric Society 55 (1):105-107. doi:10.1111/j.1442-200X. 2012.03614.x [PubMed: 23409988]

Shimkets RA, Lifton RP, Canessa CM (1997) The activity of the epithelial sodium channel is regulated by clathrin-mediated endocytosis. The Journal of biological chemistry 272 (41):25537-25541 [PubMed: 9325269]

Shimkets RA, Warnock DG, Bositis CM, Nelson-Williams C, Hansson JH, Schambelan M, Gill JR Jr., Ulick S, Milora RV, Findling JW, Canessa CM, Rossier B, Lifton RP (1994) Liddle's syndrome: heritable human hypertension caused by mutations in the beta subunit of the epithelial sodium channel. Cell 79 (3):407-414 [PubMed: 7954808]

Singer MS, Kahana A, Wolf AJ, Meisinger LL, Peterson SE, Goggin C, Mahowald M, Gottschling DE (1998) Identification of high-copy disruptors of telomeric silencing in Saccharomyces cerevisiae. Genetics 150 (2):613-632 [PubMed: 9755194]

Smith AN, Skaug J, Choate KA, Nayir A, Bakkaloglu A, Ozen S, Hulton SA, Sanjad SA, Al-Sabban EA, Lifton RP, Scherer SW, Karet FE (2000) Mutations in ATP6N1B, encoding a new kidney vacuolar proton pump 116-kD subunit, cause recessive distal renal tubular acidosis with preserved hearing. Nature genetics 26 (1):71-75. doi:10.1038/79208 [PubMed: 10973252]

Snyder PM, McDonald FJ, Stokes JB, Welsh MJ (1994) Membrane topology of the amiloride-sensitive epithelial sodium channel. The Journal of biological chemistry 269 (39):24379-24383 [PubMed: 7929098]

Snyder PM, Price MP, McDonald FJ, Adams CM, Volk KA, Zeiher BG, Stokes JB, Welsh MJ (1995) Mechanism by which Liddle's syndrome mutations increase activity of a human epithelial Na+ channel. Cell 83 (6):969-978 [PubMed: 8521520] 
Soundararajan R, Lu M, Pearce D (2012) Organization of the ENaC-regulatory machinery. Critical reviews in biochemistry and molecular biology 47 (4):349-359. doi: 10.3109/10409238.2012.678285 [PubMed: 22506713]

Sritippayawan S, Sumboonnanonda A, Vasuvattakul S, Keskanokwong T, Sawasdee N, Paemanee A, Thuwajit P, Wilairat P, Nimmannit S, Malasit P, Yenchitsomanus PT (2004) Novel compound heterozygous SLC4A1 mutations in Thai patients with autosomal recessive distal renal tubular acidosis. American journal of kidney diseases : the official journal of the National Kidney Foundation 44 (1):64-70 [PubMed: 15211439]

Stark K, Vainio S, Vassileva G, McMahon AP (1994) Epithelial transformation of metanephric mesenchyme in the developing kidney regulated by Wnt-4. Nature 372 (6507):679-683. doi: 10.1038/372679a0 [PubMed: 7990960]

Staub O, Dho S, Henry P, Correa J, Ishikawa T, McGlade J, Rotin D (1996) WW domains of Nedd4 bind to the proline-rich PY motifs in the epithelial Na+ channel deleted in Liddle's syndrome. The EMBO journal 15 (10):2371-2380 [PubMed: 8665844]

Staub O, Gautschi I, Ishikawa T, Breitschopf K, Ciechanover A, Schild L, Rotin D (1997) Regulation of stability and function of the epithelial $\mathrm{Na}+$ channel $(\mathrm{ENaC})$ by ubiquitination. The EMBO journal 16 (21):6325-6336 [PubMed: 9351815]

Stehberger PA, Shmukler BE, Stuart-Tilley AK, Peters LL, Alper SL, Wagner CA (2007) Distal renal tubular acidosis in mice lacking the AE1 (band3) Cl-/HCO3- exchanger (slc4a1). Journal of the American Society of Nephrology : JASN 18 (5):1408-1418. doi:10.1681/ASN.2006101072 [PubMed: 17409310]

Stover EH, Borthwick KJ, Bavalia C, Eady N, Fritz DM, Rungroj N, Giersch AB, Morton CC, Axon PR, Akil I, Al-Sabban EA, Baguley DM, Bianca S, Bakkaloglu A, Bircan Z, Chauveau D, Clermont MJ, Guala A, Hulton SA, Kroes H, Li Volti G, Mir S, Mocan H, Nayir A, Ozen S, Rodriguez Soriano J, Sanjad SA, Tasic V, Taylor CM, Topaloglu R, Smith AN, Karet FE (2002) Novel ATP6V1B1 and ATP6V0A4 mutations in autosomal recessive distal renal tubular acidosis with new evidence for hearing loss. Journal of medical genetics 39 (11):796-803 [PubMed: 12414817]

Strautnieks SS, Thompson RJ, Gardiner RM, Chung E (1996) A novel splice-site mutation in the gamma subunit of the epithelial sodium channel gene in three pseudohypoaldosteronism type 1 families. Nature genetics 13 (2):248-250. doi:10.1038/ng0696-248 [PubMed: 8640238]

Su Y, Blake-Palmer KG, Sorrell S, Javid B, Bowers K, Zhou A, Chang SH, Qamar S, Karet FE (2008) Human H+ATPase a4 subunit mutations causing renal tubular acidosis reveal a role for interaction with phosphofructokinase-1. American journal of physiology Renal physiology 295 (4):F950-958. doi:10.1152/ajprenal.90258.2008 [PubMed: 18632794]

Tajima T, Kitagawa H, Yokoya S, Tachibana K, Adachi M, Nakae J, Suwa S, Katoh S, Fujieda K (2000) A novel missense mutation of mineralocorticoid receptor gene in one Japanese family with a renal form of pseudohypoaldosteronism type 1. The Journal of clinical endocrinology and metabolism 85 (12):4690-4694. doi:10.1210/jcem.85.12.7078 [PubMed: 11134129]

Toye AM, Williamson RC, Khanfar M, Bader-Meunier B, Cynober T, Thibault M, Tchernia G, Dechaux M, Delaunay J, Bruce LJ (2008) Band 3 Courcouronnes (Ser667Phe): a trafficking mutant differentially rescued by wild-type band 3 and glycophorin A. Blood 111 (11):53805389. doi:10.1182/blood-2007-07-099473 [PubMed: 18174378]

Uehara Y, Sasaguri M, Kinoshita A, Tsuji E, Kiyose H, Taniguchi H, Noda K, Ideishi M, Inoue J, Tomita K, Arakawa K (1998) Genetic analysis of the epithelial sodium channel in Liddle's syndrome. Journal of hypertension 16 (8):1131-1135 [PubMed: 9794716]

van den Ouweland AM, Dreesen JC, Verdijk M, Knoers NV, Monnens LA, Rocchi M, van Oost BA (1992) Mutations in the vasopressin type 2 receptor gene (AVPR2) associated with nephrogenic diabetes insipidus. Nature genetics 2 (2):99-102. doi:10.1038/ng1092-99 [PubMed: 1303271]

van Leeuwen F, Gafken PR, Gottschling DE (2002) Dot1p modulates silencing in yeast by methylation of the nucleosome core. Cell 109 (6):745-756 [PubMed: 12086673]

Vargas-Poussou R, Houillier P, Le Pottier N, Strompf L, Loirat C, Baudouin V, Macher MA, Dechaux M, Ulinski T, Nobili F, Eckart P, Novo R, Cailliez M, Salomon R, Nivet H, Cochat P, Tack I, Fargeot A, Bouissou F, Kesler GR, Lorotte S, Godefroid N, Layet V, Morin G, Jeunemaitre X, Blanchard A (2006) Genetic investigation of autosomal recessive distal renal tubular acidosis: 
evidence for early sensorineural hearing loss associated with mutations in the ATP6V0A4 gene. Journal of the American Society of Nephrology : JASN 17 (5):1437-1443. doi:10.1681/ASN. 2005121305 [PubMed: 16611712]

Viemann M, Peter M, Lopez-Siguero JP, Simic-Schleicher G, Sippell WG (2001) Evidence for genetic heterogeneity of pseudohypoaldosteronism type 1: identification of a novel mutation in the human mineralocorticoid receptor in one sporadic case and no mutations in two autosomal dominant kindreds. The Journal of clinical endocrinology and metabolism 86 (5):2056-2059. doi:10.1210/jcem.86.5.7449 [PubMed: 11344206]

Wade JB (2011) Statins affect AQP2 traffic. American journal of physiology Renal physiology 301 (2):F308. doi:10.1152/ajprenal.00248.2011 [PubMed: 21561996]

Wang C, Chan TK, Yeung RT, Coghlan JP, Scoggins BA, Stockigt JR (1981) The effect of triamterene and sodium intake on renin, aldosterone, and erythrocyte sodium transport in Liddle's syndrome. The Journal of clinical endocrinology and metabolism 52 (5):1027-1032. doi:10.1210/ jcem-52-5-1027 [PubMed: 6262354]

Wang LP, Yang KQ, Jiang XJ, Wu HY, Zhang HM, Zou YB, Song L, Bian J, Hui RT, Liu YX, Zhou XL (2015) Prevalence of Liddle Syndrome Among Young Hypertension Patients of Undetermined Cause in a Chinese Population. Journal of clinical hypertension 17 (11):902-907. doi:10.1111/jch.12598 [PubMed: 26075967]

Wu H, Chen L, Zhou Q, Zhang X, Berger S, Bi J, Lewis DE, Xia Y, Zhang W (2013) Aqp2-expressing cells give rise to renal intercalated cells. Journal of the American Society of Nephrology : JASN 24 (2):243-252 (Editorial in the same issue of J Am Soc Nephrol pg 163-165, Selection by Faculty of 1000). doi:10.1681/ASN.2012080866 [PubMed: 23308014]

Xiao Z, Chen L, Zhou Q, Zhang W (2015) Dot1l deficiency leads to increased intercalated cells and upregulation of V-ATPase B1 in mice. Experimental cell research. doi:10.1016/j.yexcr. 2015.09.014

Xu PX, Zheng W, Huang L, Maire P, Laclef C, Silvius D (2003) Six1 is required for the early organogenesis of mammalian kidney. Development 130 (14):3085-3094 [PubMed: 12783782]

Yang B, Gillespie A, Carlson EJ, Epstein CJ, Verkman AS (2001) Neonatal mortality in an aquaporin-2 knock-in mouse model of recessive nephrogenic diabetes insipidus. The Journal of biological chemistry 276 (4):2775-2779. doi:10.1074/jbc.M008216200 M008216200 [pii] [PubMed: 11035038]

Yang KQ, Xiao Y, Tian T, Gao LG, Zhou XL (2014) Molecular genetics of Liddle's syndrome. Clinica chimica acta; international journal of clinical chemistry 436:202-206. doi:10.1016/j.cca. 2014.05.015 [PubMed: 24882431]

Yang Q, Li G, Singh SK, Alexander EA, Schwartz JH (2006) Vacuolar H+ -ATPase B1 subunit mutations that cause inherited distal renal tubular acidosis affect proton pump assembly and trafficking in inner medullary collecting duct cells. Journal of the American Society of Nephrology : JASN 17 (7):1858-1866. doi:10.1681/ASN.2005121277 [PubMed: 16769747]

Yashima T, Noguchi Y, Kawashima Y, Rai T, Ito T, Kitamura K (2010) Novel ATP6V1B1 mutations in distal renal tubular acidosis and hearing loss. Acta oto-laryngologica 130 (9):1002-1008. doi: 10.3109/00016481003631529 [PubMed: 20233014]

Yu J, Carroll TJ, McMahon AP (2002) Sonic hedgehog regulates proliferation and differentiation of mesenchymal cells in the mouse metanephric kidney. Development 129 (22):5301-5312 [PubMed: 12399320]

Yu J, Carroll TJ, Rajagopal J, Kobayashi A, Ren Q, McMahon AP (2009) A Wnt7b-dependent pathway regulates the orientation of epithelial cell division and establishes the cortico-medullary axis of the mammalian kidney. Development 136 (1):161-171. doi:10.1242/dev.022087 [PubMed: 19060336]

Zhang W, Hayashizaki Y, Kone BC (2004) Structure and regulation of the mDot1 gene, a mouse histone H3 methyltransferase. Biochem J 377 (Pt 3):641-651 [PubMed: 14572310]

Zhang W, Xia X, Jalal DI, Kuncewicz T, Xu W, Lesage GD, Kone BC (2006a) Aldosterone-sensitive repression of ENaCalpha transcription by a histone $\mathrm{H} 3$ lysine-79 methyltransferase. Am J Physiol Cell Physiol 290 (3):C936-946 [PubMed: 16236820] 
Zhang W, Xia X, Reisenauer MR, Hemenway CS, Kone BC (2006b) Dot1a-AF9 Complex Mediates Histone H3 Lys-79 Hypermethylation and Repression of ENaC $\{$ alpha $\}$ in an Aldosteronesensitive Manner. The Journal of biological chemistry 281 (26):18059-18068 [PubMed: 16636056]

Zhang W, Xia X, Reisenauer MR, Rieg T, Lang F, Kuhl D, Vallon V, Kone BC (2007) Aldosteroneinduced Sgk1 relieves Dot1a-Af9-mediated transcriptional repression of epithelial $\mathrm{Na}+$ channel alpha. The Journal of clinical investigation 117 (3):773-783 [PubMed: 17332896]

Zhang W, Yu Z, Wu H, Chen L, Kong Q, Kone BC (2013) An Af9 cis-element directly targets Dot1a to mediate transcriptional repression of the alphaENaC gene. American journal of physiology Renal physiology 304 (4):F367-375. doi:10.1152/ajprenal.00537.2011 [PubMed: 23152297] 

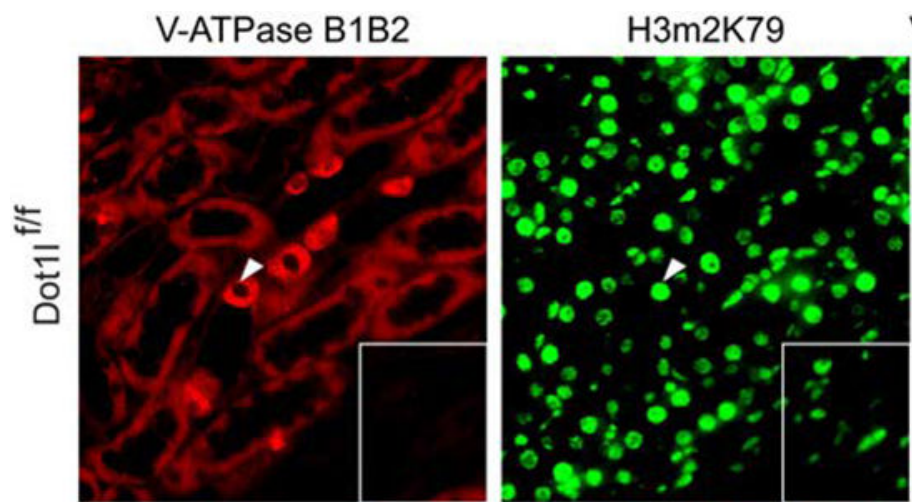

V-ATPase B1B2/H3m2K79
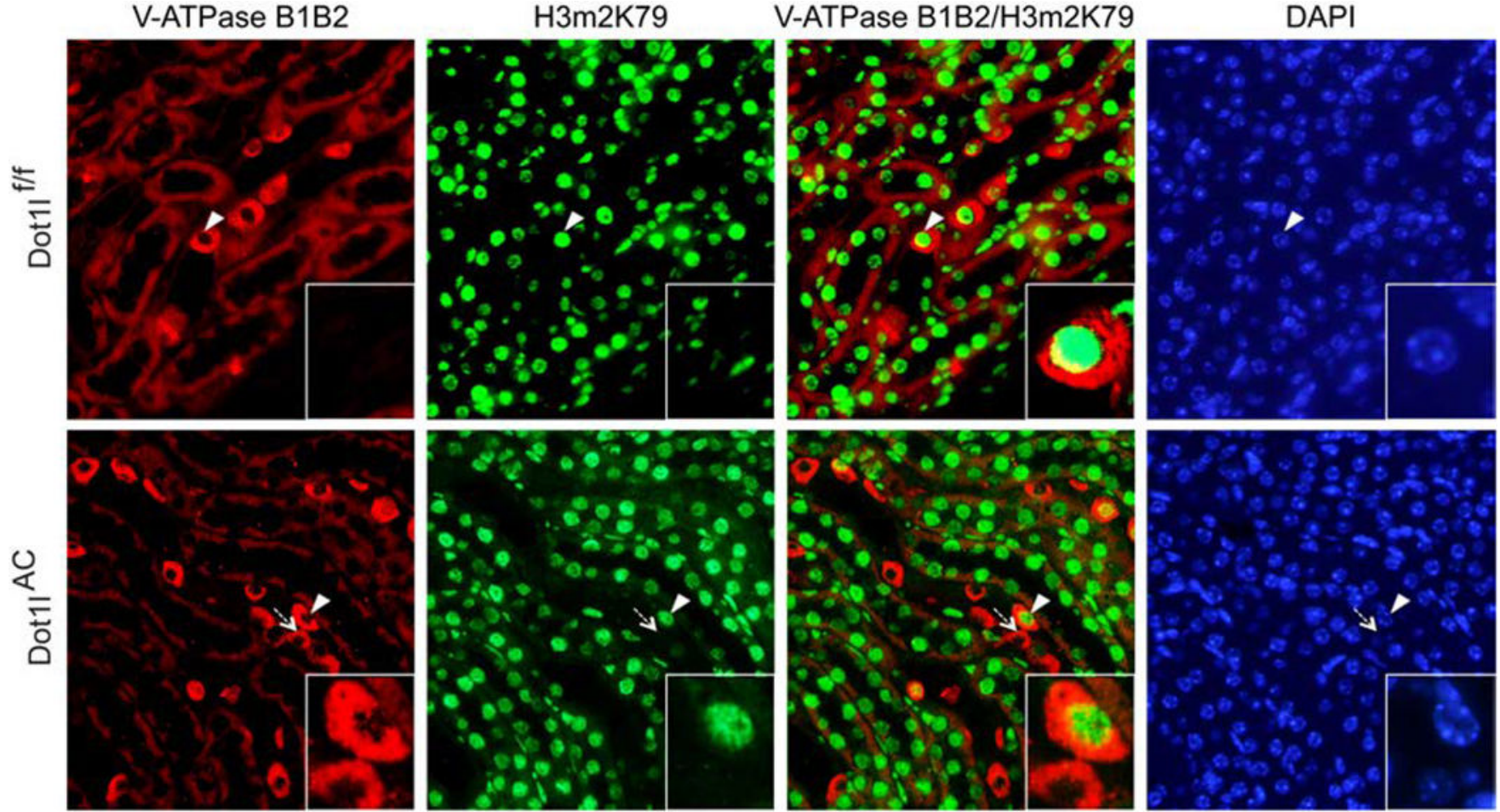

Figure 1. Loss of $\mathrm{H3m} 2 \mathrm{~K} 79$ is observed in the intercalated cells in Dot $^{A}{ }^{A C}$ mice. Kidney sections from Dot $11^{f / f}$ and Dot1 $f^{f / f}$ Aqp2Cre (Dot11 ${ }^{A C}$ ) were subjected to double immunofluorescence staining with a rabbit antibody specific for dimethyl histone H3 K79 (H3m2K79) to determine the functional status of Dot1l and a goat antibody recognizing VATPase subunits B1 and B2 to identify the intercalated cells. H3m2K79 was robustly detected in all intercalated cells in Dot $1 f^{f / f}$ mice, but undetectable in the most of intercalated cells in $D o t 11^{A C}$ mice. Hence, Cre-mediated inactivation of Dot 11 driven by Aqp2 promoter in the Aqp2Cre transgene occurs in the intercalated cells, indicating that Aqp2 promoter is activated in the intercalated cells during development. Arrow and arrowhead: Cells with abolished or intact $\mathrm{H} 3 \mathrm{~m} 2 \mathrm{~K} 79$, respectively. These cells were amplified in the inserts. Scale bar: $50 \mu \mathrm{M}$ and $16.3 \mu \mathrm{M}$ for insert. 

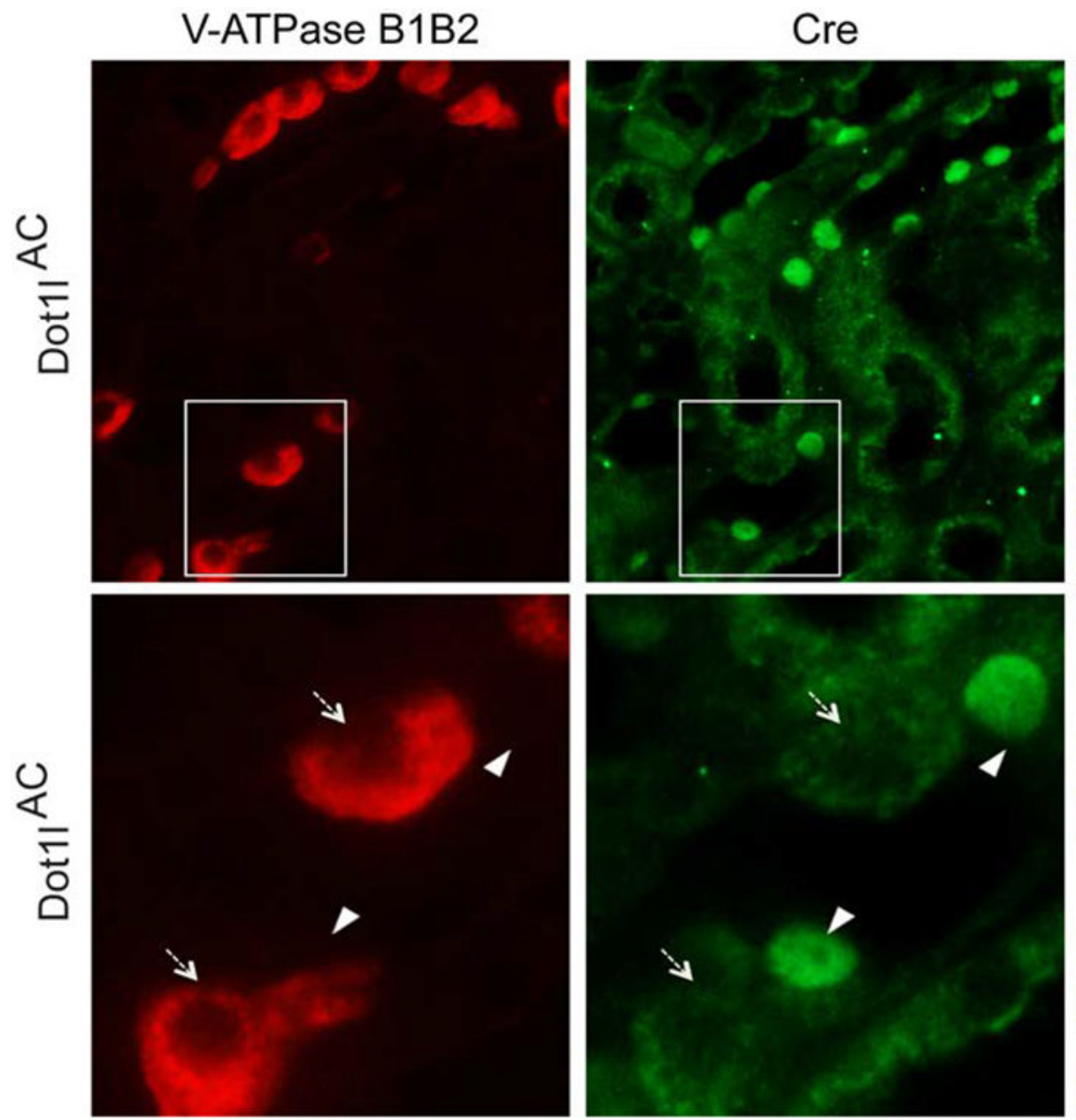

V-ATPase B1B2/Cre
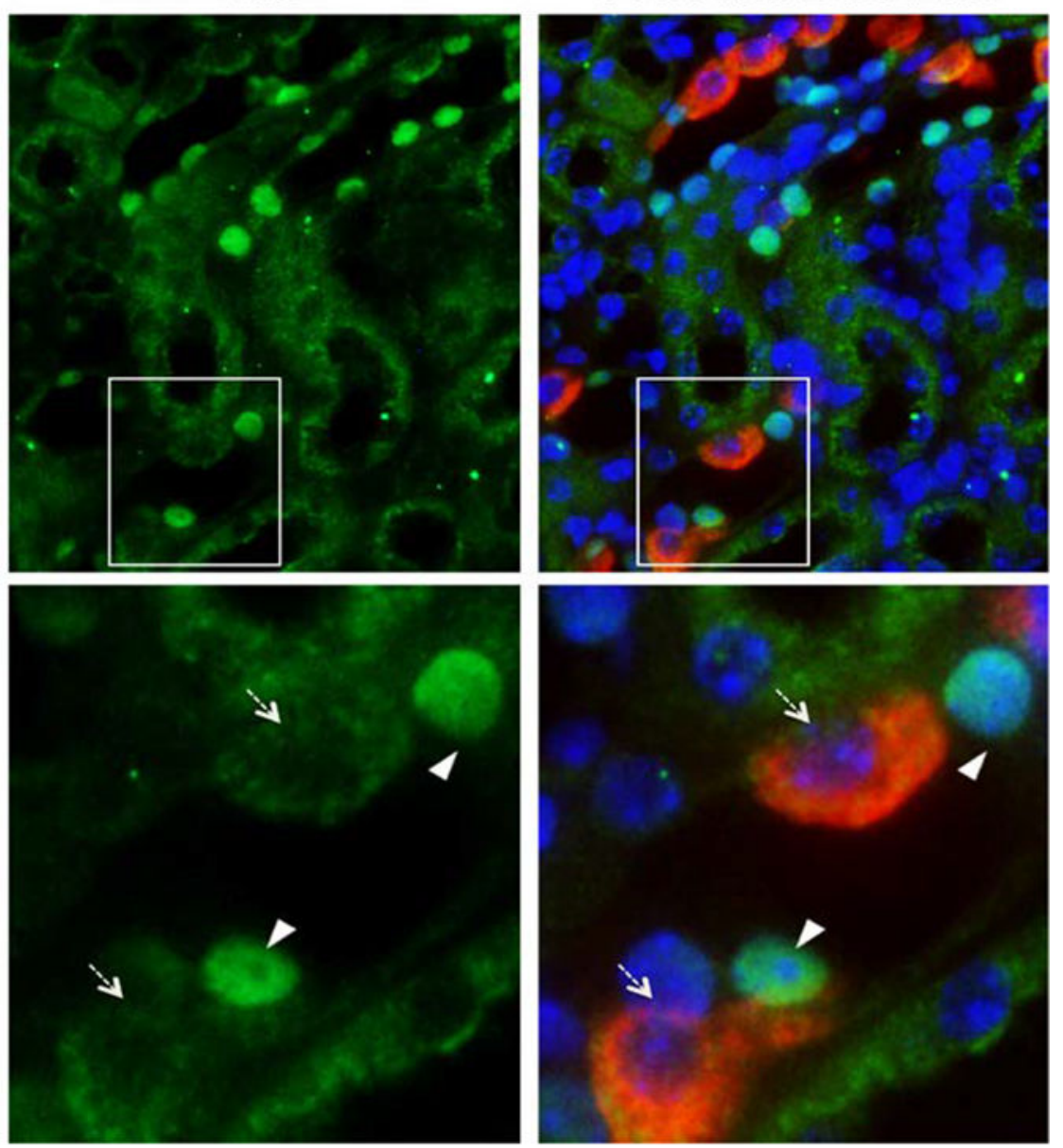

Figure 2. Loss of $\mathrm{H3m} 2 \mathrm{~K} 79$ in the intercalated cells of $\operatorname{Dot}_{11}{ }^{A C}$ mice is not due to promiscuous expression of Cre expression.

Kidney sections from $\operatorname{Dot}_{1}{ }^{A C}$ were subjected to double immunofluorescence staining with a rabbit antibody specific for Cre recombinase to detect constant and constitutive expression of Cre and the goat antibody recognizing V-ATPase subunits B1 and B2 to identify the intercalated cells. Cre is robustly detected in B1B2- tubular cells, which are principal cells that have constant and constitutive Aqp2 expression. However, Cre is undetectable in the intercalated cells, suggesting that $A q p 2$ promoter is silenced after the Aqp $2^{+}$progenitor cells are differentiated into the intercalated cells during development. Arrow: $\mathrm{B} 1 \mathrm{~B} 2^{+} \mathrm{Cre}^{-}$ (Intercalated cells). Arrowhead: B1B2- ${ }^{-} \mathrm{Cre}^{+}$(Principal cells). Boxed area is magnified and shown at the bottom. Scale bar: $50 \mu \mathrm{M}$ (top) and $16.3 \mu \mathrm{M}$ (bottom). 
Table 1.

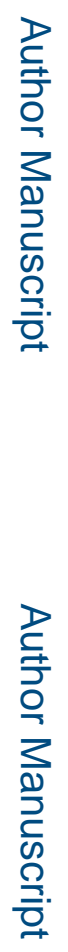

Genetic diseases of collecting duct

\begin{tabular}{|c|c|c|c|c|}
\hline Disorder & OMIM\# & Inheritance & Gene & Gene Product \\
\hline \multirow[t]{2}{*}{ Liddle's syndrome } & \multirow[t]{2}{*}{177200} & \multirow[t]{2}{*}{$\mathrm{AD}$} & $S C N N 1 B$ & $\beta \mathrm{ENaC}$ \\
\hline & & & $S C N N 1 G$ & $\gamma \mathrm{ENaC}$ \\
\hline \multirow[t]{4}{*}{ PHA1 } & \multirow[t]{3}{*}{264350} & \multirow[t]{3}{*}{$\mathrm{AR}$} & SCNN1A & $\mathrm{aENaC}$ \\
\hline & & & $S C N N 1 B$ & $\beta \mathrm{ENaC}$ \\
\hline & & & $S C N N 1 G$ & $\gamma \mathrm{ENaC}$ \\
\hline & 177735 & $\mathrm{AD}$ & $N R 3 C 2$ & Mineralocorticoid receptor \\
\hline \multirow[t]{4}{*}{ dRTA } & 179800 & $\mathrm{AD}$ & SLC4A1 & AE1 \\
\hline & 611590 & \multirow[t]{3}{*}{$\mathrm{AR}$} & $S L C 4 A 1$ & AE1 \\
\hline & 267300 & & ATP6V1B1 & V-ATPase B1 \\
\hline & 602722 & & ATP6VOA4 & V-ATPase a4 \\
\hline \multirow[t]{2}{*}{ NDI } & $\begin{array}{l}304800 \\
300539 \\
\end{array}$ & XLR & $A V P R 2$ & Arginine vasopressin receptor- 2 \\
\hline & 125800 & $\mathrm{AD}, \mathrm{AR}$ & $A Q P 2$ & $\mathrm{AQP} 2$ \\
\hline
\end{tabular}

